PROTECTION OF NATIONALS ABROAD: THE MEXICAN STATE AND

THE SEASONAL AGRICULTURAL WORKERS IN CANADA

by

Karla Angélica Valenzuela Moreno, BA, Universidad de Las Américas, Puebla, 2008

\author{
A Major Research Paper \\ presented to Ryerson University \\ in partial fulfillment of the requirements for the degree of \\ Master of Arts \\ in the Program of \\ Immigration and Settlement Studies
}

Toronto, Ontario, Canada, 2011

CC Karla Angélica Valenzuela Moreno 2011 


\section{Author's Declaration}

I hereby declare that I am the sole author of this major research paper.

I authorize Ryerson University to lend this paper to other institutions or individuals for the purpose of scholarly research.

Signature

I further authorize Ryerson University to reproduce this paper by photocopying or by other means, in total or in part, at the request of other institutions or individuals for the purpose of scholarly research.

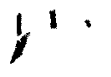

Signature 


\title{
PROTECTION OF NATIONALS ABROAD: THE MEXICAN STATE AND THE SEASONAL AGRICULTURAL WORKERS IN CANADA
}

Karla Angélica Valenzuela Moreno

Master of Arts, 2011

Immigration and Settlement Studies

Ryerson University

\begin{abstract}
Due to the adverse economic conditions in Mexico and the need for offshore labour in Canadian agriculture, Mexico entered the Seasonal Agricultural Worker Program (SAWP) in 1974 as a source country, becoming the country that exports the highest number of agricultural workers to Canada. While abroad, these workers have genuine needs that should be addressed by the Mexican government, but unfortunately the Mexican government has failed to provide adequate protection to its nationals. This paper offers an overview of the situation in rural Mexico, the operational aspects of the program and its violations; it identifies the workers' needs and the most important national and international documents that regulate the protection of nationals abroad. This research is a critique of the role of the Mexican government in the protection of the seasonal agricultural workers in Canada, identifying the limitations that the State faces for providing protection to its nationals.
\end{abstract}

\section{Key Words:}

labour migration; Mexican consulates; Seasonal Agricultural Worker Program; rural Mexico; protection of nationals abroad. 


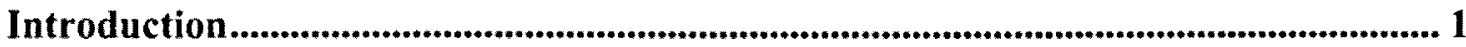

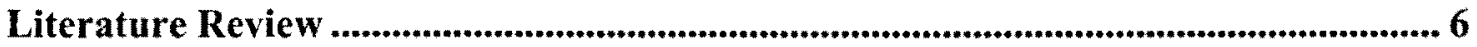

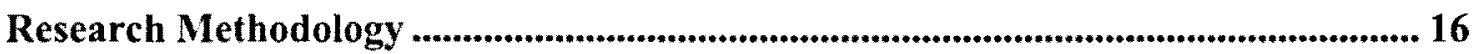

CHAPTER I: The situation in rural Mexico and Mexico's Participation in the

Seasonal Agricultural Worker Program ................................................................ 20

Mexico's inclusion in the $S A W P$............................................................................ 24

CHAPTER II: Legal Aspects and Implementation of the Seasonal Agricultural

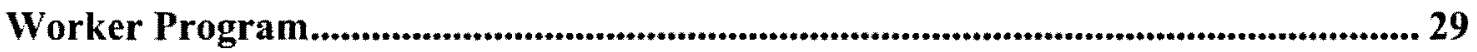

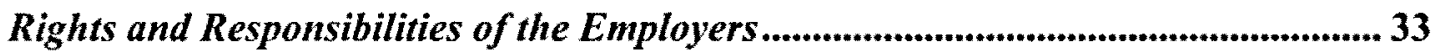

Rights and Responsibilities of the Workers ......................................................... 33

The Exploitative and Discriminatory Nature of the Program ................................. 35

Violations to the Agreement for the Employment with Mexico ................................ 38

Specific Discriminatory Conditions for Mexican Workers ........................................ 40

CHAPTER III: 'Protection' of Nationals Abroad and the Seasonal Agricultural

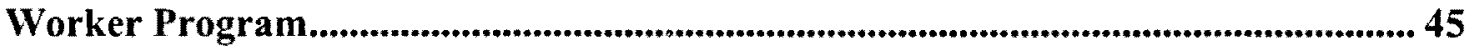

International Framework for the Protection of Nationals Abroad ............................ 45

Vienna Convention on Consular Relations of 1963 .......................................... 47

North American Agreement on Labor Cooperation of 1994 .................................. 49

Mexican Framework for the Protection of Nationals Abroad .................................. 51

The Mexican State protecting the SAWP workers ................................................ 52 
Limitations to the protection of Mexican agricultural workers in the SAWP 56

Grassroots organizations and unions as an alternative for the protection of Mexican agricultural workers 62

Discussion 65

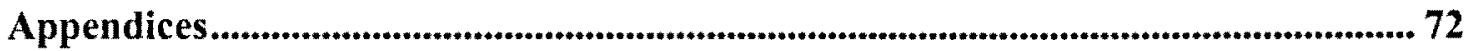

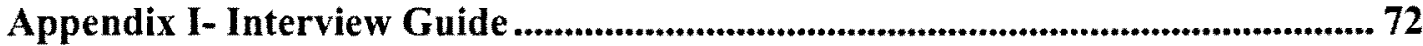

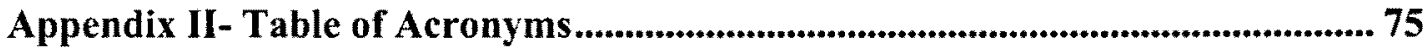

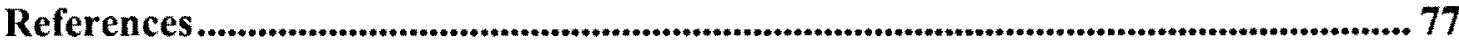




\section{Introduction}

This paper intends to investigate whether the protection that the Mexican State provides to the seasonal agricultural workers employed in Canada addresses the needs and problems of these workers. It offers an overview of the situation in rural Mexico and the operational aspects of the Seasonal Agricultural Worker Program (SAWP), as well as its exploitative nature. It links my research findings about the SAWP to legal frameworks related to the protection of nationals abroad and it evaluates the performance of the Mexican State in relation to the protection it provides for the workers.

Unlike most Canadian immigration programs, the SAWP is a temporary migrant labour program with no option for permanent residency, even though the average time that most workers spend in Canada is between four and eight months a year. In addition to this long period of time, the nature of the employment contract restricts the mobility of the workers, as it binds them to a single employer. Due to the inability of the farm workers to negotiate the terms of their employment elsewhere, they are forced to endure discrimination, exploitation, unsanitary living conditions, sexual harassment (particularly for women), and all sorts of abuses committed by the employers, especially given the fact that the workers can be easily repatriated. Furthermore, the temporary status of the workers makes them ineligible for many employment benefits, social assistance programs, and severe disabilities benefits, even though they do contribute to Employment Insurance and the Canada Pension Plan.

The SAWP was implemented in 1964 and Mexico was included as a source country in 1974 . This program was introduced as a result of the constant demands from 
Canadian growers to contract a cheap, 'unskilled' agricultural workforce, which was unavailable in the national workforce. The rural population of developing countries (unable to find employment in their own countries) met the growers' demands. In addition to filling employment gaps, the foreign workers are subject to exploitative conditions that increase the productivity of Canadian farms. Nowadays, offshore labour is not only more convenient for Canadian growers, but it has become a 'structural necessity' for Canada's agriculture (Basok, 2002), and I would also argue that this 'structural necessity' has expanded to the source countries of the SAWP, as temporary migrant labour is no longer the exception, but has now become the rule. Furthermore, some sectors of the Canadian economy heavily rely on temporary migrant labour, and for the source countries, the program is not just another option, but ironically, it is the only job opportunity available.

Due to the adverse conditions of the Mexican economy and the situation in its rural areas, this program is indeed necessary for the survival of many Mexican families, whose main source of income was agriculture. The productivity of their lands has deteriorated due to the implementation of neo-liberal policies, which have caused a significant cut to subsidies in agriculture, while favouring disproportionate negotiations between transnational companies and family farms (González-Amador, 2009). Furthermore, the signing of NAFTA also contributed to the decadence of Mexican small farms. Therefore, despite Mexico's late inclusion in the SAWP, the exploitative nature of the program (specifically for Mexicans), and the unsafe and abusive conditions under

\footnotetext{
'Although the labour performed by foreign farm workers in Canada is generally considered 'unskilled', certain types of skills are indeed required to work in agriculture.
} 
which agriculture is practiced in Canada, Mexico is now the biggest supplicr of foreign labour for the Canadian agricultural industry.

In spite of the exploitations the workers are subjected to, both the workers themselves and the Mexican government benefit from the SAWP. On the one hand, the livelihood of workers slightly improves with their enrollment in the program, although the SAWP represents a 'poverty alleviation strategy' as opposed to a development program' (Binford, 2006, p. 1). On the other hand, for the Mexican government it represents a constant source of remittances and employment for the rural population, which it is not possible to create at the national level given the current economic conditions and the state of rural poverty.

This paper also presents a critique of the Mexican government, which has failed to develop a constructive labour policy, and instead has continued exporting its labour force to capitalist economies. Due to the lack of a coherent national labour policy, the Mexican institutions involved in the SAWP, and, more importantly, the workers, have to pay a high price for their participation in the program; the former spend a considerable amount of money on administrative procedures, while the latter are subject to discriminatory and exploitative conditions that are institutionalized under the SAWP.

According to domestic legislation as well as international law, the Mexican State is obligated to provide adequate protection for its nationals abroad. Given the presence of Mexican seasonal agricultural workers in Canada, the government is compelled to provide assistance and develop public policies that improve the protection services offered to this group of co-nationals in Canada. The Mexican government is both legally and morally compelled to assist and protect the workers enrolled in the SAWP: the state 
has the legal obligation to protect its nationals abroad, and since the government has been unwilling or unable to develop the necessary conditions for the workers to find employment within the country, then the State (by means of the appropriate institutions) is responsible for the wellbeing of its nationals abroad. Due to the inadequate and insufficient protection provided by the Mexican government, the workers have engaged in community organizing activities of grassroots NGOs that oftentimes offer them the assistance that they do not receive from the Mexican State.

This paper argues that despite the responsibility of the Mexican State to assist its nationals abroad, the seasonal agricultural workers have genuine needs that are not being addressed by the Mexican government. Due to the scarce sources of literature on the topic, I also conducted interviews to complement the secondary research. The literature on the SAWP and the protection of nationals abroad, along with the analysis of relevant international agreements and Mexican laws, has allowed me to explore the following questions: What are the workers" needs in Canada that are not being addressed by the Mexican government? Why are these needs not being addressed?

While this paper is a critique of the Mexican government with respect to the protection of its farm workers in Canada, it also sheds light on the difficulties faced by Mexican officers, who are under pressure to protect the workers' rights without interfering in their competitiveness vis-à-vis workers from other source countries of the SAWP.

The first chapter discusses the situation in rural Mexico, the economic restructuring of the country, and how it led to the deterioration of its agriculture. It also refers to Mexico's inclusion in the SAWP as a result of the dynamics between the 
economies in the Global North and South. The second chapter provides a legalistic framework of the SAWP, explaining the most important aspects of the documents that regulate the program, as well as the rights and responsibilities of the farm workers and the employers. The last section of the chapter refers to all the violations committed by the employers, and the discriminatory attitudes towards the Mexican workers. Chapter three analyzes the responsibility of the State to provide protection for its nationals abroad. It examines national and international mechanisms that regulate the protection of nationals abroad and that are pertinent to the SAWP. It then discusses the limitations that the Mexican State faces when protecting the seasonal farm workers, and examines the role of grassroots organizations. Finally, the paper concludes with a discussion that highlights the main findings and provides a detailed answer to the research questions. 


\section{Literature Review}

Due to the overwhelming numbers of Mexicans residing in the United States ( $98 \%$ of all Mexicans abroad), most of the Mexican research on the protection of nationals abroad is US based, and the SAWP workers have been overshadowed by the needs of irregular immigrants in the US. In addition to its population in the United States, the Mexican government is also responsible for providing adequate services to its nationals throughout the world, including those participating in the SAWP.

Although the SAWP has been broadly researched by many academics in Canada and it is starting to be a relevant topic for scholars in Mexico as well, little knowledge has been produced on the protection that the Mexican State offers to the SAWP workers. This paper intends to fill this gap by analyzing the correlation between the protection of foreign nationals and the Mexican seasonal agricultural workers in Canada.

The literature I analyzed focuses on the rural situation in Mexico, the exploitative nature of the program, the legal aspects of the SAWP, the experiences of workers while they are in Canada, their needs, and the different ways they organize and resist. The literature that refers to the Mexican Consulates in Canada and the services they provide to the workers was particularly useful for my topic.

\section{Rural Mexico and the exportation of its workforce}

Leigh Binford (2009) and Diego-Quintana (2004) discuss the policy changes in Mexico, especially during the late 1980 s and 1990 s when the country privatized the rural banking system, reduced the subsidies allocated to assist farmers, and adopted neo-liberal policies with the signing of the North American Free Trade Agreement (NAFTA). Binford found that the neo-liberal economic restructuring and the low birth rates in the 
Global North relate with the need for low wage labour in sectors such as construction, the hospitality industry, meatpacking and agriculture. Diego-Quintanta argues that Mexican farmers were unable to become entrepreneurs due to the disappearance of the government institutions that formerly provided assistance for the farmers. Even though the intentions of the Mexican government by adopting the neo-liberal policies was to modernize the agriculture industry in Mexico, this transformation was not possible and the result was the impoverishment of farmers and their families.

Fitzgerald (2009) analyzes the situation of farmers in Mexico, and the way it has become a country of emigrants due to the impoverishment of its rural areas, the overcrowding of big, industrialized cities, and the structural adjustments. He concludes that, among other factors, the lack of adequate development policies addressed to the most vulnerable populations has caused the massive displacement of Mexicans to developed countries. Mackinlay-Grohmann (1993) presents an in-depth study of the Mexican land reforms in the Constitution of 1992 in a historical perspective. He argues that these reforms put an end to the distribution of land to farmers, and that the decree that modifies article 27 of the Constitution privatized the property of lands, allowing private companies to invest in agriculture and livestock breeding. He also argues that the government has been unable to provide the assistance required for the development of agriculture, resulting in the decadence of rural areas and the impoverishment of farmers and their families.

Verduzco-Igartúa (2008) mainly focuses on the statistical data about the workers' socioeconomic characteristics. He analyzes the progress of Mexican families involved in the program, and whether or not the SAWP represents a positive change in their 
socioeconomic status, and the implications for the family life of the workers. The author concludes by stating that the wages received by Mexican farm workers in Canada contribute to a slight improvement in the workers' well being, which is mainly reflected in higher educational achievements of their children. Furthermore, he argues that these types of temporary labour migration are beneficial for the workers, since they represent a constant source of labour with higher incomes. However, he does not touch upon the fact that temporary labour programs are only a temporary remedy for developing countries, and that more sustainable solutions are needed in order to better respond to the Mexican farmers' needs.

\section{Global Restructuring and the Need for Temporary Migrant Labour}

Tanya Basok is the author of several academic papers that explain the relationship between Canada's labour market and the need for offshore labour. Her book Tortillas and Tomatoes (2002) explains the implementation of non-immigrant employment programs under a Marxist framework. She provides three economic theories that explain the need to implement programs such as the SAWP, namely segmented labour market theory, global restructuring, and foreign workers as a surplus population. Through the development of these theories, she explains why migrant labour has become a 'structural necessity'. Through the theoretical development of economic theories regarding migrant labour, she highlights the inequalities of immigrants in the labour market and the benefits that precarious labour conditions bring for the accumulation of capital in developed countries.

Vic Satzewich (2007) writes about Mexico's inclusion in the SAWP, and explains it as a result of the desire of Canadian growers to reduce the bargaining power of the 
Caribbean countries. Furthermore, he provides a historical background of seasonal agricultural labour in Canada, focusing on the conflicting interests of Canadian farmers and government officials in receiving and sending countries as an important factor of policy-making. He also explains the conditions of agriculture in Ontario before and after the implementation of the program, and the need for offshore labour to fill the employment gaps, as well as to increase the productivity of Canadian agriculture.

Lowe (2008) argues that global and neo-liberal restructuring are important factors in the displacement of people, and that they cause greater inequalities between the Global North and South. The liberalization of trade and privatization of lands have led to exchange deficits for developing countries. Lowe (2008) and Isa (1998) state that developing countries are unable to enforce their labour laws and are even lowering their labour standards in order to promote foreign investment. Poor labour standards also translate into migrant labour movements, since migrants are unable to find suitable working conditions in their country of origin.

The treatment of farm workers under The Seasonal Agricultural Worker

\section{Program}

Lutz \&Vizcarra-Bordi (2007) compare and contrast the opinions of Mazahua migrant women between migrating to Canada or the United States. They start by describing the exploitative aspects of the SAWP and misinformation about the program. They also explain how Mazahua women build their own perceptions of the program based on experiences of relatives, since migration is still highly masculinized in their community. They further analyze the women's expectations from Canada and the United States, and conclude that most women prefer their relatives to migrate to Canada, as they 
think of it as more organized and less risky than the United States. Furthermore, the authors also focus on the family ties of migrants during the migration process.

Kerry Preibisch focuses on the gender dimensions of the program, reporting on special circumstances and social interactions of women in the SAWP. In her article (in co-authorship with Santamaria) Engendering Labour Migration: The Case of Foreign Workers in Canadian Agriculture (2006) she has also studied the selection process of workers prior to their arrival in Canada, and the way the gender roles of home countries play out during the women's stay in Canada. She found that Mexican officials promote migrant women by recommending Canadian growers to hire women for the strawberry harvesting, arguing that they are 'particularly' suited for that kind of job, and thus reproducing gender stereotypes. She concludes that there are deficiencies in the Canadian and the Mexican institutions with respect to the operational guidelines of the SAWP.

Preibisch has also published in collaboration with Evelyn Encalada, a researcher and activist who dedicates most of her work to the exposure of the vulnerable situation of workers with regard to living and working conditions, premature repatriation, accidents in the workplace, and lack of proper insurance and accurate information. In their article The Other Side of El Otro Lado (2010) they analyze the vulnerable working and housing conditions of the workers, especially the women. Furthermore, Encalada has also written about organizing and resistance of temporary foreign workers, and has led resistance movements herself through Justicia 4 Migrant Workers, a pro-migrant NGO.

Leigh Binford and Tanya Basok criticize the lack of labour mobility of the workers, emphasizing that workers are unable to switch employers and are bound to arbitrary behavioural rules of the farms. Basok has also done primary research in 
communities such as Leamington, Ontario, where she has studied the mechanisms of exclusion that Mexican workers are subject to, as well as the 'ethnic replacement'. She highlights the involvement of community centres in the integration of farm workers, and the legal rights of migrant workers prescribed in international conventions. They emphasize the temporary status of the workers as a control mechanism and a legal basis for denying migrant workers certain rights and benefits.

To enrich the literature review, I also included Earth to Mouth (2001), a documentary about the life of seasonal agricultural workers that discusses the life of Mexican immigrants and their positive relationship with the Chinese employers. It also shows the types of jobs the workers perform, the health risks involved in their daily tasks, their perceptions about the program, and the limitations they have due to language barriers. The documentary depicts a clear picture of what farming represents for the halfdozen Mexican workers employed on the farm: "It provides jobs that help them support their children back home." El Contrato (2003) is another documentary that criticizes Canadian and Mexican governments for the implementation and administration of the SAWP. It clearly reflects the inadequate protection granted to Mexican workers in Leamington, and the indifference of Mexican officials towards severe violations of the workers' rights.

Basok (2004) documents in a very comprehensive way some of the violations committed to the Agreement for the Employment, starting with the inappropriate housing. This unsuitable accommodation violates the Agreement, which stipulates the obligation of the employer to provide suitable accommodation that should meet the approval of the authority responsible for health and living conditions, or the government 
agent. She also analyzes the legal barriers that make workers ineligible for paid holidays and vacations, and some employment benefits.

Satzewich (2007) also emphasizes the precarity of the workers' living conditions and presents a survey conducted between 2001 and 2003 in Ontario, which revealed that Canadian citizens were paid between $9 \%$ and $14 \%$ more than migrant workers. This situation contradicts the Agreement for the Employment, which states that Mexican workers should be paid the same amount as Canadian workers doing the same type of work. Satzewich also argues that in spite of clear violations to the Agreement for the Employment with Mexico, Canadian growers receive no real sanction for their unlawful actions. Relevant to the topic is the fact that sending countries are also unable to force Canadian farmers to comply with the rules, since they have limited bargaining power, and they are also competing with the other source countries.

Delgado-Bailón (2008) studies the SAWP from the Mexican perspective, and focuses on the role of Mexican institutions involved in the SAWP. She presents the activities carried out by the Mexican Secretariat of Labour in the recruitment of seasonal workers. She found that the requirements of the Mexican Secretariat of Labour are not the same as those required in the Agreement for the Employment. The author also describes the hardships that workers have to go through in Mexico in order to enroll in the program, such as traveling to Mexico City coming from the provinces and the misinformation provided by the Mexican authorities. Furthermore, she emphasizes that the lack of proper training and equipment that farm workers receive, the violations of the rules prescribed in the Agreement for the Employment, the dangerous conditions under 
which Canadian agriculture is practiced, and the misinformation, puts the farm workers even more at risk of suffering accidents in the workplace.

\section{The Protection of Nationals Abroad}

With respect to the protection of nationals abroad, most literature focuses on the consular access for people who are at risk of being sentenced to death in a foreign country. However, the relevant literature explains the legal duties of the sending government delegated on its consular posts. They all emphasize the right of the nationals abroad to contact and receive assistance from the government they are bound to by nationality, as well as the responsibility of that government to provide assistance to its nationals abroad.

Chatterjee (2007) writes about the historical background and development of consular posts and diplomacy, emphasizing the diplomatic context and providing the definitions of common terms in international law. Quigley, Aceves and Shank (2009) explain the role that consuls play in assisting a national, the concept of 'protection activity' and 'protection officers' as well as the origins of the Vienna Convention on Consular Relations. They also address the privileges and special circumstances of consular officers that allow them to protect their nationals in a better manner. Uribe (1997) made a holistic study about consular posts and human rights, in which he highlights the importance of the protection activities above all the other duties of the consulates. Uribe also outlines the different ways in which a consulate is expected to provide assistance, and the different approaches that the States can take with respect to the right to consular protection, including Mexico. 
Warren (2008) analyzes Mexico's legal framework with respect to the protection of its nationals and its historical evolution. He addresses the Law on the Mexican Foreign Service and its regulations, and the different mechanisms that the Ministry of Foreign Affairs has implemented as a means of assistance for its population abroad. However, he focuses entirely on the situation of Mexicans in the United States.

Leigh Binford criticizes the performance of the Mexican authorities in relation to the protection of the workers. He argues that the Mexican consulates have a dual task that is hard to manage: on the one hand, they have to protect the workers from the abuses committed by the growers, and on the other hand, they need to keep Mexican workers 'marketable' enough. In his article From Fields of Power to Fields of Sweat: The dual process of constructing temporary migrant labor in Mexico and Canada (2009), he argues that Mexican Consulates are under pressure to maintain a good relationship with Canadian growers, which negatively affects the support they provide to the workers, as they often side with the employers instead of the workers. He has also studied the situation in rural Mexico and concluded that the SAWP is only an 'alleviation' of the poverty and does not represent a real solution (2006).

Verduzco-Igartúa (2008) also addresses the performance of the consulate-general of Mexico in Toronto, its limitations, the efficacy of its services, and the workers' opinions about the attitudes and services provided by the consular officers. He concludes by saying that the Consulate needs to implement programs that are suitable to the workers' needs. An important contribution of his research is about the changes that the Agreement for the Employment has undergone and how they negatively affect not only the workers, but the Mexican government as well. 
This paper complements the academic literature with the documents that contain the legal framework and guidelines of the SAWP, in order to determine the obligation of the Mexican State to protect its seasonal agricultural workers. 


\section{Research Methodology}

I chose the critical social research method to conduct my research. This methodology suggests that social reality has several layers, multiple structures and mechanisms. It considers that society is not static, it identifies and exposes social problems, investigates the conditions under which these issues are developed and encourages positive changes where needed (Neuman, 2003). Furthermore, it takes into account real experiences of people relevant to the research, showing their oppression and pointing to ways in which this oppression can be changed (Seiler, n.d.).

This interdisciplinary approach, in addition to interviews with a Mexican public servant and an activist, allowed me to identify and discuss the social problems that derive from the oppression of Mexican agricultural workers and the inadequate protection provided by the Mexican State while they work abroad. Even though the workers believe that the conditions under which they work are acceptable, I critically assess these working conditions and highlight the exploitative aspects of their employment in Canada. Moreover, I analyze the protection provided by the Mexican State and highlight the responsibility of the government to offer adequate protection to the workers. In addition to the legal responsibility of the State to protect its co-nationals, Mexico has an even stronger commitment towards its rural population due to the lack of economic opportunities provided to them in the national sphere.

My literature review comprises the literature related to the need for temporary migrant labour and the economic dimensions of the SAWP; discrimination, abuses, and vulnerabilities of the farm workers; and the legal framework for the protection of nationals abroad. I also analyzed several legal and policy documents: the Memorandum 
of Understanding, its Operational Guidelines, the Agreement for the Employment of Mexican Workers, and Mexican and international legislation concerning the protection of migrant workers and nationals abroad, such as the Vienna Convention on Consular Relations of 1963 and the North American Agreement on Labor Cooperation of 1994. I also included information obtained from reports made by the research area of the Mexican Senate.

Furthermore, I consulted international treaties and agreements relevant to the subject. The United Nations has several international conventions that outline the basic human rights and the protection of migrant workers, such as the Charter of the United Nations (1945), The Universal Declaration of Human Rights (1948), and the International Convention on the Protection of the Rights of All Migrant Workers and Members of their Families (1990), which promote the fundamental human rights of all individuals regardless of sex, race, religion, etc. I also analyzed the Vienna Convention on Consular Relations (1963), which outlines the regulations for the organization and duties of the consular posts. In addition, I consulted the North American Agreement on Labor Cooperation, especially the sections related to the standards of employment.

With regard to the Canadian legal framework, I examined Section 15 of the Canadian Charter of Rights and Freedoms relative to all forms of discrimination. In the Mexican context, I analyzed the contents of the Law on the Mexican Foreign Service and its regulations, as well as reports from the Mexican Senate related to the operational aspects of the SAWP. With respect to the Law on the Mexican Foreign Service, I particularly studied the legal duty of the public servants to safeguard the rights of Mexicans abroad and the organization of the Consular Posts in Canada. The reports of the 
Mexican Senate were only relevant in terms of analyzing the institutional response regarding the SAWP.

In addition to the literature review, my original research plans were to also conduct three semi-structured interviews with closed and open-ended questions that would serve as a guideline for the interviews, but the participants would be encouraged to provide additional information and share their experiences and points of view as well (see Appendix I). The informants I was interested in interviewing were a Mexican public servant in Mexico City, an activist with experience working with Mexican seasonal agricultural workers, and a consular officer at the consulate-general of Mexico in Toronto. The reason I decided not to interview farm workers is that their needs are well documented in the academic literature and I have had the opportunity to meet some workers and visit their workplace due to my involvement with the grassroots organization Justicia 4 Migrant Workers.

Despite many attempts, the consular officer refused to be interviewed, and I had to do extra research on Mexican Consulates in Canada, mainly on the Consulates' websites and official public documents that refer to Mexican Consulates or the Secretary of Foreign Affairs and its special Under-Secretary for North American Affairs. One of my biggest challenges was to find detailed information on the protection programs offered by the Mexican Consulates in Canada, since most of the information on their websites relates to the requirements to apply to the SAWP. Furthermore, most of the information on protection programs for Mexicans is related to the US. Regarding the availability of sources, the academic literature that addressed my topic in particular was very scarce, and 
thus I had to complement it with an analysis of national and international legislations and government reports relevant to the SAWP.

Another significant challenge was to conduct the interview with the Mexican public servant in Mexico City. As was to be expected, at the beginning his responses were very institutional and he portrayed a defensive attitude. However, by the end of the interview I was able to gain in-depth knowledge about legal issues regarding the SAWP, as well as the public servant's personal opinion about the program and protection granted to Mexican workers.

The knowledge produced through the interviews and the legal analysis allowed me to identify the loopholes in the legislation of the SAWP; it especially helped me to detect those rules left intentionally 'unspecified', so that employers can interpret them at their convenience ${ }^{2}$. The interview with the public servant, the policy documents, and the legislations and rules analyzed generally complemented each other and agreed on one statement: the SAWP is beneficial for the governments of Mexico and Canada, as well as for the workers. However, the activist and the academic literature raised important issues (such as ethnic replacement, systemic discrimination, isolation of the workers, conditions of the workers' quarters, etc.) that were ignored by the public servant and are supposedly prohibited by law.

The interviews that were successfully conducted, as well as the legal analysis, allowed me to have a better understanding of the topic, know the institutional position of the Mexican government about the SAWP, and shape the findings of my research, which are incorporated below.

\footnotetext{
2 These regulations are discussed in detail in Chapter II, Violations to the Agreement for the Employment with Mexico.
} 


\section{CHAPTER I: The situation in rural Mexico and Mexico's Participation in the Seasonal Agricultural Worker Program}

According to Felipe Calderón (the current Mexican President) 'You have two economies. One economy is intensive in capital, which is the American economy. One economy is intensive in labour, which is the Mexican economy. We are two complementary economies, and that phenomenon is impossible to stop.' (Binford, 2009, p. 504) This statement reflects the unwillingness and/or inability of the Mexican government to work on the root causes that lead to the human displacement of Mexicans to the US and more recently to Canada. Judging by Calderón's words, we can expect that issues such as inequalities in land distribution, labour conditions and low wages in Mexico will remain unattended, and as a result, the exploitation, vulnerability and abuse of co-nationals abroad will continue, at least until someone more sensitive and socially conscious replaces him at the end of his mandate.

In fact, the American and the Mexican economies are far from being complementary; while the former remains strong, the latter weakens as it loses its labour force and human capital and suffers from depopulation of its rural areas, whose displaced members end up engaging in irregular or inhumane international migration, or at the peripheries of bigger and industrialized cities. Rather than being complementary, the broken Mexican economy is contributing to the development of the American and Canadian capitalist economies. Furthermore, the Mexican economic structure is complicit in the perpetuation of the differences between the North and South, and the abuses 
against Mexican migrants, whose personal and family lives are affected due to this phenomenon that the President considers 'impossible to stop'.

In other words, labour supply and demand set the rules for immigration policy, and the labour supply needs of the US and Canada are met by migrant labour from developing countries such as Mexico (Fitzgerald, 2009). In the Mexico-Canada context, the dichotomy between North and South leads us to explore the situation in rural Mexico in order to have a better understanding of the nature and operational aspects of the SAWP.

The economic restructuring in Mexico had a huge impact on the migration patterns of its rural population. Important economic restructuring took place during the post-World War II period in Mexico, which led to unfavourable situations in the Mexican agricultural industry. Firstly, due to government policies the price of food was kept low to contribute to capitalist accumulation in the bigger cities. Secondly, the oil crisis in 1973 and the debt crisis in 1983 caused structural dislocations and led to a shift to neoliberalism. Mexico began to experiment with privatization of the rural banking system, a dismantlement of institutions that supported small and medium-sized farms (Tabamex, Fertimex, Inmecafe, etc.), and the weakening of the Secretary of Agriculture, the Secretary of the Land Reform, and Banrural (Binford, 2009; Diego-Quintana, 2004). The disappearance of these public institutions was a mechanism that the government utilized to force them to sell their services through the private market. The government also implemented trusteeships that were intended to become private consultancy firms that would substitute the counselling formerly given by public institutions, which proved to be an unsuccessful practice (Diego-Qunitana, 2004). 
There were several determinants that contributed to the decay in the Mexican agriculture sector: the signing of the Punta del Este Declaration under the General Agreement on Tariffs and Trade in 1986, specifically the provisions about the reduction of quantitative restrictions and the elimination of tariffs for trade; the introduction of the land amendment provision of the Constitution in $1992^{3}$ (Mackinlay-Grohmann, 1993); the refusal of the State to enforce its labour laws in order to encourage Foreign Direct Investment (Isa, 1998); and the signing of the North American Free Trade Agreement (NAFTA) in 1994 (Binford, 2009). NAFTA contributed to intensified trade that led to import substitutions. The increasing imports of corn and sorghum, which are grains that are also produced in national soil, left many southern farmers out of business, provoking an internal migration of southern workers moving north, where most industrial cities are located $^{4}$ (Mackinlay-Grohmann, 1993; Consejo Nacional Agropecuario, 2008; Pastor, 2010).

More specifically, the provisions of NAFTA that allowed the liberalization of the grain trade, caused a drop in government assistance to farms, multinationals taking over grain commercialization, and an increase in US imports. Mexican agriculture suffered the transition from 'food self-reliance' to 'food insecurity', in which the country relies on imports for its food supply. These imported products are cheaper because the producers benefit from big State subsidies (Alba, 2008). The goal that the Mexican government pursued with the signing of NAFTA was that Mexican farmers would either modernize in

\footnotetext{
3 The most significant amendments were privatization of the lands and the conclusion of land distribution (Mackinlay-Grohmann, 1993).

4 According to Consejo Nacional Agropecuario (2008), the grain import before the NAFTA accounted for 8.4 million tons, and in 2006 it was a total of 17.4 million tons.
} 
order to stay competitive or shift occupations. Binford cites former Finance Minister Fernando Canales: 'The campesinos (farmers) will have to transform themselves into industrial workers or true businesspeople, particularly the poor corn and bean producers.' (2009, p. 506) This expected transition of Mexican farmers from growers to businessmen did not happen. The reason has been that the population in rural Mexico lacks the education and the financial support from the government in order to change occupations. Furthermore, the government is not committed to creating a social safety net or building a strong and reliable economy. All these factors left farmers without work and with no other choice but to migrate.

In unsuccessful attempts to stop the further impoverishment of Mexican farmers, the federal government has signed agreements with the US and Canada to promote organized labour emigration. From 1942 to 1964 Mexico had an agreement with the United States called the Bracero Program, which both governments deemed successful. Moreover, some academics argue that one of Mexico's purposes with the signing of the SAWP is to encourage the United States to enter into a similar agreement and reduce irregular migration (Satzewich, 2007). From the perspective of the Mexican government, seasonal work programs have been favourable for the workers and represent an escape valve for the poor economic conditions present in the country and a constant flow of remittances (Fitzgerald, 2009; personal communication with Mexican Officer, June 7, 2011). For some academics and activists this type of migration means the institutionalization of unfree labour and precarious conditions for vulnerable populations in developing countries, who enrich and strengthen capitalist economies while meagerly 
improving their livelihoods. Both the receiving and the sending countries share responsibility for the deterioration of the life conditions in the Global South.

\section{Mexico's inclusion in the SAWP}

According to Human Resources and Skills Development Canada (HRSDCRHDSC) the SAWP allows the organized entry of workers to meet the needs of Canadian agriculture in sectors like vegetables, tender fruits, tobacco, apples, apiary, ginseng, nurseries, greenhouse vegetables and sod (2010). Ever since 1964, Canada has employed foreign nationals to work on farms. First, it admitted 264 seasonal migrant workers from Jamaica and in 1967 Trinidad and Tobago and Barbados joined the program. In 1974, Mexican and Portuguese workers were added to foreign labour on Canadian farms (Basok, 2002). In that year, only 195 Mexicans were employed, but by 2006 Mexico sent 12,825 workers (Luz \& Bizcarra-Bordi, 2007), outnumbering any other sending country from the Caribbean (HRSDC, 2010). The above section explained the reasons why the Mexican government was interested in participating in a temporary migrant labour scheme, and this section explains the motivations for Canada to agree on Mexico's inclusion in the SAWP.

The needs of Canadian agriculture greatly influenced the entrance of the Mexican agricultural labour force. Mexico was added to the pool of foreign workers because Canadian federal immigration officers wanted to reduce the bargaining power of Caribbean governments on behalf of their workers. Besides, the entrance of the Mexican labour force helped maintain the supply of cheap labour, keeping wages down and maintaining Canada's competitive prices. Furthermore, the employers began to worry 
about the complaints from the Caribbean workers regarding the working conditions (Preibisch \& Encalada, 2010). In sum, the decision to hire Mexican workers related to the 'race to the bottom' and ethnic replacement, which in this specific case refers to the replacement of Caribbean workers by Mexicans due to racialized discourses and stereotypes perpetuated mostly among Canadian growers (Preibisch \& Binford, 2007).

According to Satzewich, during the 1970 s the Canadian federal bureaucracy was going through a legitimacy crisis that questioned its ability to provide Ontario's agricultural businesses with the supply of labour they needed. Ontario farmers alleged that 'crops were rotting in the field for want of workers' (2007, p. 268). In July 1973, a Task Force was appointed to assess the situation of the farms in Ontario. The Task Force discovered that farmers were employing undocumented workers to fill the employment gaps at their farms. It reported existing 'brokers' in Ontario who were charging Mexican Mennonite families to find jobs for them on farms and transported them by bus from El Paso, Texas to Canada (Satzewich, 2007; Basok, 2002).

The Ontario Federation of Labour (OFL) also advocated for the inclusion of Mexico in SAWP. It feared that without a federally administered program, undocumented workers would continue to be employed under deplorable working and living conditions. However, the labour community would later disregard the conditions for Caribbean and Mexican workers (Basok, 2004). In 1974, ten months after the first Task Force Report was made public, the Minister of Manpower and Immigration announced that the Government of Canada had signed a Memorandum of Understanding with Mexico regarding the admission of Mexican seasonal agricultural workers into Canada. The inclusion of female migrant workers was not until 1989, when Canadian farmers started 
to request them. Women now represent $3 \%$ of the labour force, but this number has been rapidly increasing (Verduzco-Igartúa, 2008) because Canadian growers think that women are 'more suitable than men' to perform certain kinds of tasks like strawberry harvesting or activities related to horticulture. It may also be possible that in some cases women are preferred because they are thought to be more vulnerable and manageable than men. The reasons for including women clearly illustrate the gendered dimension of the program (personal communication with activist, June $25^{\text {th }}, 2011$; Preibisch \& Santamaria, 2006).

Satzewich considers that despite the reasons mentioned above, the inclusion of Mexican workers in the SAWP was somewhat contradictory. The 1970s were a time of economic crisis for the Caribbean, and thus the governments of these countries were requesting to send more workers to Canada. Moreover, Caribbean workers did not have communication problems, as their mother tongue is English. This commonality with one Canadian official language also meant that they required less supervision. Finally, the fact that some Caribbean countries were once British colonies like Canada makes the Caribbean workers more adaptable (2007). Far from being a contradiction, I would argue that the characteristics that made the Caribbean workers more suitable to adapt in Canada are in fact the reason why Mexicans were included in the program: the less adaptable and more vulnerable the workers are, the less bargaining power they have to negotiate their working conditions. In this specific situation, Mexican workers lack the knowledge of the official languages, which represents a barrier to exercise some of their rights (insurance, pension benefits, etc.), socialize with the local population, and argue with their employers. 
Since 2002, the pool of foreign low-skilled workers has increased with the new pilot project in the Agricultural Stream of the National Occupation Classifications (NOC) $\mathrm{C}$ and $\mathrm{D}$, which allows employers to recruit agricultural foreign workers from any country under the Foreign Worker Program (HRSDC, 2011a). The inclusion of more source countries into agriculture has meant a decrease in the number of temporary foreign workers from Mexico in Quebec, where Guatemalans started to be preferred in the agriculture business due to their even more vulnerable condition. Moreover, the introduction of new source countries has caused animosity and competition among workers and thus it has diminished their capacity for collective bargaining (RoffeGutman \& Lapalme, 2009).

Current statistics of the program indicate that up to May 2011, the Mexican States that have sent the most workers are the State of Mexico $(1,977)$, Tlaxcala $(1,333)$, Guanajuato (734), Veracruz (649), and Puebla (672), and the total number of workers sent is 10,290 (Dirección de Movilidad Laboral de la Coordinación General del Servicio Nacional de Empleo, May 2011). According to statistics from the Dirección de Protección en el Resto del Mundo y Asuntos Especiales in Mexico, the number of foreign workers in 2010 was lower than in 2008 and $2009^{5}$. The drop in the number of workers in 2009 was due to the H1N1 virus (personal communication with public servant, June $7^{\text {th }}$, 2011). However, the government did not reach the goal of 16,000 workers in 2010 (Poder Ejecutivo Federal, 2011). Nonetheless, in my interview with the government official, he said that he did not have any statistics indicating that the extension of the Temporary

\footnotetext{
5 In the year 2008 15,849 workers participated in the SAWP, 15,356 in 2009 and in 2010 there were only 15,808, which represcnts a decline of 41 workers compared to 2008 (personal communication with a Mexican official, June 7, 2011).
} 
Foreign Worker Program for the NOC C and D had any negative effects on the number of Mexicans that farmers employ. 


\section{CHAPTER II: Legal Aspects and Implementation of the Seasonal Agricultural Worker Program}

The legal basis for the SAWP is Section 10 (c) of the Immigration Act and Immigration Regulations of 1978 that deals with noncitizens who are authorized to work in Canada. This section allows the entrance of foreign workers provided that there is an agreement between Canada and the country of origin of the workers (Commission for Labor Cooperation, 2002). The program is drafted by a specific bi-lateral agreement called a Memorandum of Understanding (MOU) along with a set of Operational Guidelines and an Agreement for the Employment of Mexican Workers, that contain the guidelines and responsibilities of the Canadian and Mexican governments as well as of the workers and employers (Commission for Labor Cooperation, 2002; HRSDC, 2010). According to the MOU, the Mexican government is responsible for assisting in the recruitment, selection, and documentation of bona-fide agricultural workers; maintaining a pool of workers who are ready to depart to Canada when requests are received from Canadian employers; appointing agents at their embassies/consulates in Canada to 'assist Citizenship and Immigration Canada (CIC) and Human Resources and Skills Development Canada (HRSDC-RHDC) staff in the administration of the program; and to serve as a contact point for the workers (e.g. working conditions, employer complaints, etc.). (HRSDC, $2010,2^{\text {nd }}$ par.).

Each year, the MOU and the Agreement for the Employment establish more restrictive and disadvantageous conditions for the workers and increase the administrative cost for the Mexican government. For instance, previous versions of the MOU established that the office of HRSDC must inform the Secretariat of Labour in Mexico of 
how many and which Mexican workers are required for the season. The current version has reduced that period to twenty days. However, in practice the HRSDC commonly gives a ten-day notice, which makes it difficult for the office to recruit the workers in a timely manner (Verduzco-Igartúa, 2008).

The Mexican government is required to have a certain number of backup workers in case Canada's labour needs require more workers than expected. This number rose from 100 to 300 workers (HRSDC, 2011), which means that the government of Mexico has to process more applications and perform more medical examinations, which increases the cost of the program for the government of Mexico. For example, in 2002, 10,681 workers went to Canada, but 11,659 applications were processed. The expenses in medical examinations are also an aspect that has increased the cost of the program (Verduzco-Igartúa, 2008). At the early stages of the SAWP, a doctor from the Canadian Embassy in Mexico examined the workers. Nowadays, The Mexican Secretariat of Health is responsible for subsidizing the medical examination costs. In 2002, the SAWP cost was included in the Mexican National Budget, which accounted for $\$ 23,396,454$ pesos (about $\$ 2,029,180$ USD). The administrative costs were slightly under $\$ 200$ USD per worker, not including the transportation aid of $\$ 3,000$ pesos (around $\$ 260$ USD) that new participants receive. If we include the transportation aid, the average cost per worker is just under \$270 USD (Embassy of Mexico in Ottawa, 2006; Verduzco-Igartúa, 2008).

Canada has designated HRSDC and CIC as the main operators of the SAWP. When Canadian growers are interested in employing foreign workers, they have to submit proof that they unsuccessfully tried to recruit Canadians for the vacant jobs through a Labour Market Opinion (LMO). HRSDC is in constant communication with CIC and the 
Canadian Embassy in Mexico to recruit and issue the appropriate documentations for the workers (HRSDC, 2010).

The Mexican institutions involved in the operation of the SAWP are the Ministry of Health, the Ministry of Foreign Affairs, and the Secretariat of Labour and Social Welfare. The Ministry of Health assesses that the workers are in optimal condition to work abroad. The Ministry of Foreign Affairs is in charge of the political matters surrounding the program, the issuance of traveling documents and the protection of the workers' rights through the consulate. The Secretariat of Labour, through the General Coordination of Employment (Coordinación General de Empleo), is in charge of handling the program and recruiting the workers (Delgado-Bailón, 2008).

An upgrade of the program has been the implementation of the Local Labour Service Offices (LLSO) that work under the supervision of the Secretariat of Labour and are located in different states so that workers do not have to travel to Mexico City. The tasks of the LLSOs are to promote the program and contact the workers that have been called by Canadian employers. Unfortunately, these offices cannot perform any other tasks due to the lack of budget for training personnel, which is very unfortunate for the workers, as they have to spend money and time traveling to the central offices in Mexico City for most of the application process ${ }^{6}$. Furthermore, most workers reported that the program office provided more information about the kind of work than about their legal rights (Verduzco-Igartúa, 2008). Another improvement of the program has been the establishment of more health centres that have been certified by Canadian authorities and that are now able to perform the workers' pre-departure medical examination. In previous

\footnotetext{
- In 2002 the Mexican government granted each new worker $\$ 3000$ Mexican pesos to subsidize his/her trips to Mexico City (Verduzco-Igartúa, 2008).
} 
years, there were only five health centres allowed to do this examination, all of which were in Mexico City. There are now more health clinics spread around the States of San Luis Potosi, Puebla, Tlaxcala, State of Mexico, Oaxaca, Jalisco, and Yucatán (Embassy of Mexico in Ottawa, 2006).

Foreign Agricultural Resource Management Services (FARMS) and Fondation des Entreprises en Recrutement de Main-d'oeuvre agricole Étrangère (FERME) (in Quebec, Prince Edward Island and New Brunswick) are private institutions responsible for the operation of the SAWP in Canadian provinces (Delgado-Bailón, 2008). The program currently operates in nine provinces, namely Prince Edward Island, Nova Scotia, New Brunswick, Quebec, Ontario, Manitoba, Saskatchewan, Alberta and British Columbia (HRSDC, 2010). In 2009, there was a total entry of 27,654 seasonal agricultural workers in Canada and the provinces that received the largest number of workers were Ontario $(17,989)$ and Quebec $(3,754)(\mathrm{CIC}, 2010 \mathrm{~b})$. Similarly, most of the Mexican workers are concentrated in Ontario and Quebec (Embassy of Mexico in Ottawa, 2006; Verduzco-Igartúa, 2008).

In order to have a better understanding about what the workers' needs are and how the Mexican government addresses them, I will now discuss the rights and responsibilities of the employers and the workers as defined by the Agreement for the Employment. 


\section{Rights and Responsibilities of the Employers}

The employers in Canada are responsible for providing adequate housing and meals ${ }^{7}$, cooking utensils, and fuel; partial roundtrip transportation ${ }^{8}$; at least two rest periods of 10-minute duration, paid or not paid, according to provincial legislation; payment of weekly wages that would be the minimum wage paid to a Canadian doing the same type of job; maintenance of work records and statement of earnings; meeting and transporting the worker from the point of arrival in Canada to the place of employment, and at the end of the contract transporting the worker to the place of departure from Canada; getting the worker's consent and the approval of HRSDC before the transfer of the worker to another employer; providing the worker with protective clothing and formal or informal training; paying those workers who have five or more consecutive years of employment a recognition fee of $\$ 4$ per week to a maximum of $\$ 128$; where applicable, taking the worker to obtain health coverage and arranging his or her transportation to a hospital or clinic, and cooperating with the Consulate to ensure proper medical attention (HRSDC, 2011b).

\section{Rights and Responsibilities of the Workers}

Depending on the province the workers are in, they are subject to different labour rights, since these vary by province. According to the Provincial Employment Standards Act of Ontario, the workers have the right to vacation and public holiday pay if they have been employed for at least 13 weeks and are part of the Ontario Health Insurance Plan.

\footnotetext{
3Te employer may deduct from the workers" wages a sum that should not exceed $\$ 6.50$ per day to partially cover the cost of the meals (HRSDC, 2011).

8 The transportation is initially paid by the employer and then periodically deducted from the workers' paycheck up to the amount of $\$ 632$ CAD (HRSDC, 2011).
} 
Since workers make contributions to Employment Insurance (EI) and Canada Pension Plan through regular deductions from the salary, they are entitled to receive some benefits deriving from them (Basok, 2004). However, given their temporary status and the fact that they are bound to one employer, they are ineligible for EI regular benefits (which include benefits for people who lose their jobs) and they are only entitled to receive maternity/parental benefits, compassionate care benefits, and, in certain circumstances, sickness benefits (Justicia for Migrant Workers \& CSSP, n.d.). According to the Employment Agreement, most of the employer's obligations are supervised by the 'government agent', who is a public servant of the government of Mexico stationed in Canada to assist in the operation of the SAWP (HRSDC, 2011b). However, due to the scattered locations of the farms, the lack of monetary and human resources of the Consulates, and the competition that other source countries represent, this supervision is rarely enforced in the appropriate manner.

The Employment Agreement states that the period of labour will not exceed 240 hours in a 6-week term or less, nor will the term exceed the 8 months. The agreement states the normal working day as consisting of 8 hours, but the hours can be extended up to a limit of 12 hours daily. The contract grants the workers one day of rest for each 7 days of work, but it also allows this day to be postponed.

The agreement also states that other deductions include non-occupational health insurance, which the employer shall recover by regular payroll deductions at a rate of $\$ 0.60$ per day in Ontario, Quebec, and Saskatchewan, and $\$ 1.28$ in all other provinces. The worker must also obey all the employer's rules 'relating to the safety, discipline and the care and maintenance of property' (HRSDC, clause IX-3, 201 lb). Furthermore, the 
growers may deduct from the worker's wage the cost to the employer to keep the quarters clean. In certain circumstances, the worker is responsible for covering the expenses of premature repatriation. The workers are also required to return to Mexico at the end of the labour contract and are bound to one employer per season (HRSDC, 2011b).

The workers also have a re-entry authorization (permiso de doble retorno), which grants them the right to travel to Mexico and come back to Canada during the working season if they consider that there are conditions in the home country that require their presence. These conditions may range from family emergencies to local holidays or celebrations. The cost of the transportation is negotiated between the employer and the worker (personal communication with public servant, June $7^{\text {th }}, 2011$ ).

Having examined the rights and responsibilities of employers and workers, it is evident that the workers are at a disadvantage, and that the rights legally granted to them (such as the days of rest and cleaning and maintenance of the living spaces) can easily be removed, since they are subject to the productivity of the farms and the employer's whims. Furthermore, the workers may have to pay unexpected expenses due to situations that are out of their control, such as premature repatriation and re-entry authorizations. We can clearly observe that preserving the competitiveness of Canadian farms has priority over the workers' human rights and rights granted through the Agreement for the Employment.

\section{The Exploitative and Discriminatory Nature of the Program}

Indeed, the general conditions of the agricultural labour in Canada make this type of occupation undesirable, exploitative, and discriminatory for all workers regardless of their citizenship. There is a systemic discrimination of agricultural workers, which 
involves certain practices and regulations implemented at the institutional level, that prevent the workers from accessing certain benefits, such as receiving the benefits of certain laws against discrimination in the workplace and minimum employment standards, provincial insurance, social assistance, workers' compensation, and smaller amounts for severe disabilities (personal communication with activist, June $25^{\text {th }} 2011$, Commission for Labor Cooperation, 2002).

Moreover, agricultural workers are not allowed to unionize in most provinces. Although the International Labour Organization (ILO), through United Food and Commercial Workers (UFCW), issued a complaint against Canada and Ontario under the ILO Convention 87: Freedom of Association and Protection of the Right to Organize, the Canadian Supreme Court ruled against the collective bargaining of agricultural workers in the province of Ontario, declaring that this prohibition does not violate the Charter of Rights and Freedoms (Preibisch, 2011). The reason that motivated the highest court of Canada to take this position is that, according to them, the Agricultural Employees Protection Act (AEPA) does allow the farm workers to engage in collective bargaining with their employers. This statement stretched the interpretation of 'collective bargaining' '...to conclude employers in the agricultural sector have a duty to engage in meaningful discussions with their employees in good faith and make reasonable efforts to reach an agreement (National Union of Pubic and Federal Employees, 2011, par. 9).

Section 15 of the Canadian Charter of Rights and Freedoms (1982) states the equality of all individuals and provides protection against all forms of discrimination on the basis of '...race, national or ethnic origin, colour, religion, sex, age or mental or physical disability...' or any 'analogous characteristics' (section 15-1). However, 
Canadian courts have ruled against classifying occupational status as a personal characteristic that needs protection against discrimination, which means that the disadvantageous treatment of agricultural workers cannot be considered unconstitutional under section 15 of the Charter (Commission for Labor Cooperation, 2002).

The unfavourable conditions mentioned above worsen when the agricultural worker is employed under the SAWP. Satzewich (2007) distinguishes two main exploitative features of the program: the right of temporary residence only, and the binding of the workers with one specific employer, which some academics have considered to be a form of 'unfree labour'. This term refers to the politically and legally restrained ability of the workers to freely choose their employers, the recruitment criteria, and the legal and social dynamics that act as 'control mechanisms' to dominate the workers' lives in and outside the workplace (Basok, 2002). The unfounded deportations are another major criticism of the program. In the event that the workers are fired or unable to work for any reason, they are automatically deportable. It is this fear of 'deportability', and not deportation itself, that renders workers more vulnerable to exploitation (Binford, 2009; De Genova \& Peutz, 2010). Another hardship that most workers have to go through is related to their particular ethnicities, which make them a visible minority. Their physical appearance, particular clothing, and lack of knowledge of any of the official languages, make the workers an easy target for discrimination in Canadian stores and entertainment establishments. Furthermore, Lowe (2008) argues that some local businesses profit from the presence of the workers and raise the prices of articles in demand during their stay. In addition to benefiting Canadian farms, seasonal agricultural workers have also generated many informal businesses that cater to the 
workers' specific needs, such as second-hand clothing sales, Latin music dance saloons, ethnic food businesses, etc.

To better identify the different kinds of exploitation and discriminatory attitudes embedded in the program specifically for Mexicans, I have separated the general violations to the Agreement for the Employment with Mexico from the specific discriminatory conditions for Mexican workers that are not related to the agreement.

\section{Violations to the Agreement for the Employment with Mexico}

Working in agriculture is considered to be one of the most dangerous jobs in Canada. There is a high risk of accidents due to pesticides and other chemical products, and handling machinery. Even though the Agreement stipulates that the employer provide the worker with appropriate clothing, and 'formal or informal training and supervision where required by law' (HRSDC, 2011b, clause VIII-3) a high percentage of workers do not receive either the appropriate training or the required equipment, which puts them at even more at risk (Delgado-Bailón, 2008). Furthermore, since the clause specifies that the training can be 'formal' or 'informal', employers could easily say that informal training was given, and thus justify their compliance to the Agreement while saving the expense of providing formal training.

According to the Agreement, the normal working day should be 8 hours, which can be extended to 12 hours in urgent harvest conditions (HRSDC, 2011b, clause I-2). However, in a study conducted by Verduzco-Igartua (2008), he found that workers were self-reporting working days that averaged 9.3 hours, and some even 17 hours. Again, the flexibility of the working hours permitted by the agreement makes workers legally exploitable. Since the employer is supposed to pay for extra hours, workers do not mind 
exceeding the permitted limit, and employers benefit from the economic vulnerability of the farm workers. Moreover, the isolated locations of most farms may have a certain influence on workers deciding to work extra time, since there are no available places for entertainment or leisure activities nearby.

In terms of housing, there have been complaints about overcrowding, dysfunctions in the air conditioning or heating systems, unsanitary conditions, and lack of appliances (Basok, 2004; Preibisch \& Santamaria, 2006). This unsuitable accommodation violates clause II-1 of the Agreement that stipulates the obligation of the employer to provide suitable accommodation for the 'worker' that should meet the approval of the authority responsible for health and living conditions or the government agent. The fact that workers are housed near the employers also represents a disadvantage: the short distance between them makes it easier for employers to ask 'favours' from workers, such as working on weekends or late in the evenings (personal communication with activist, June $25^{\text {th }} 2011$; Satzewich, 2007).

With regard to salary, a survey conducted between 2001 and 2003 in Ontario revealed that Canadian citizens were paid between $9 \%$ and $14 \%$ more than migrant workers (Satzewich, 2007), which contradicts clause III-3 of the Agreement that states that Mexican workers should be paid the same amount as Canadian workers doing the same type of work (HRSDC, $2011 \mathrm{~b}$ ). As mentioned before, the workers also have the right to paid holidays and vacations. However, since there is a misunderstanding in the application of the Employment Standards Act between 'harvest' and 'farm' workers',

\footnotetext{
9 'Only harvest workers are entitled to paid public holiday and vacation benefits and only if they have been employed for 13 wecks as harvesters. Most Mexicans work in Canada for more than 13 weeks but during the term of their employment they perform numerous tasks, some related to harvesting and others to preparation of the soil, packaging, and some post-harvest activities (Basok, 2004, p. $16)^{*}$.
} 
some growers pay for vacations only as a reward (Basok, 2004). Another violation to the Agreement is the right to one day off for every six consecutive days of work. Since the Agreement also allows the employer to postpone the day off 'until a mutually agreeable date' (Basok, 2004, p.16), during harvest season many workers are asked to work the full week, including half day on Sunday.

Although the workers have the right to receive EI benefits, they are considered ineligible for some of these benefits. Since one of the requirements is to be 'ready, willing, and able to work' and agricultural workers are bound to one employer, once they stop working for this particular employer they are considered not available to work and therefore ineligible. Moreover, most benefits require the worker to remain in Canada, so for those who have left the country or have been deported, receiving these benefits is even more difficult (Justicia 4 Migrant Workers \& CSSP, n.d.).

Even though the workers' mobility is restricted due to the conditions of the MOU and the Agreement for the Employment, which bind them to one employer, Canadian farmers further restrict the workers' mobility and control their activities by withholding their passports and forbidding them to go out at night, even during their free days.

\section{Specific Discriminatory Conditions for Mexican Workers}

There are certain difficulties faced by Mexicans in particular that derive mainly from ethnic stereotypes, language barriers, and misinformation about the program (Preibisch \& Encalada, 2010; Preibisch \& Hermoso-Santamaría, 2006; Basok, 2002;

Basok, 2004; Lutz \& Vizcarra-Bordi, 2007). Once the contract period is over, employers fill out an 'end of the year' evaluation form, in which they assess the workers' performance. Upon the workers' arrival in Mexico, they are required to report their 
arrival to the Mexican Secretariat of Labour and hand in the evaluation forms in sealed envelopes (Basok, 2004). The decision on whether to select the worker for the next year's recruitment highly depends on these evaluations, and thus Mexican workers are afraid to complain and sometimes consent to exploitation (Sook Lee, 2003). Those workers who are recalled by employers are known as 'named workers' and they constitute between $48 \%$ and $68 \%$ of the Mexican workers sent to Canada (Verduzco-Igartúa, 2008). The workers who are evaluated favorably without being named usually are recruited again but transferred to another farm. The workers that receive negative comments can be banned from the program for a period of one to two years, or even expelled from it permanently (Satzewich, 2007).

The Mexican Secretariat of Labour promotes the program as an alternative of safe employment for unemployed Mexican agricultural workers to be able to economically provide for their families. This promotion of the program is partially false: it is true that working in Canada brings an economic benefit to the workers, but the economic improvement is only a temporary remedy for their economic pressures. The jobs are not practiced in the safest conditions possible, and there are negative effects for their family ties, as well as their health and mental well being (Sook Lee, 2003; personal communication with activist, June $25^{\text {th }}, 2011$ ). There are other discrepancies between the recruitment criteria of FARMS and the Mexican Secretariat of Labour. In no part of the MOU is it stipulated that only married and male workers are eligible, plus the minimum age is 18 years old with no minimum of education required. Nevertheless, the Secretariat advertises an age range of 23 to 43 years old, a level of education between elementary and high school, and gives preference to workers with strong family ties in Mexico 
(Delgado-Bailón, 2008). The young age, strong family ties, and basic education benefit the employers (George \& Young, 2006). The younger the workers are, the longer they can perform the physical work, and the less educated they are, the lower their wage expectations are. As for the family ties, this works as a guarantee that the workers will not try to stay in Canada, and instead will be eager to go back to their families.

One of the biggest problems for Mexican workers is the language barrier. Unlike the Trinidadians or Jamaicans, the great majority of Mexican workers do not speak English and some of them are illiterate, and this poses great difficulties in terms of accessing medical services, claiming benefits or making complaints (Preibisch \& Encalada, 2010). For example, at the age of 65, every Mexican worker who has made at least one contribution to the Canada Pension Plan is entitled to receive this benefit (Western Agriculture Labour Initiative, n.d.). However, many workers are unaware of the procedures needed to claim it. A similar situation occurs with the reimbursement of the prescription drugs purchased (Basok, 2004). Although Mexican workers are entitled to compensation for injuries at work from the Workplace Safety and Insurance Board, very few intend to claim it. Even though doctors who treat injured workers are required to report the injury to the Workplace Safety and Insurance Board, they fail to do so due to the language barrier, since some of the paperwork involves statements from the workers and translators are not readily available (Sook Lee, 2003). Even in the cases where the injury is reported and the forms are sent, the workers cannot fill them out by themselves (Basok, 2004) and oftentimes assistance is not available.

The language barrier has also served as a tool for isolation. Compared to West Indian workers who are English speakers and have managed to make friends with local 
residents, Mexicans find it harder to communicate with neighbours and perform everyday tasks like grocery shopping. However, particularly in Leamington, there are some residents who speak Italian, and the similarity of this language to Spanish has facilitated the communication of Mexicans with locals (Basok, 2002). Furthermore, some Mexican workers have engaged in relationships with Canadians, often breaking the language barrier.

It is ironic how the same characteristics of the Mexican workers (deemed to be natural or intrinsic to their ethnicity) serve to praise them and exploit them at the same time. Many employers prefer workers that are submissive and that please them, thinking that these qualities are part of the 'Mexicanness' (Hermoso-Santamaria, 2008; Satzewich, 2007). What the employers fail to realize is that these characteristics are not related to the Mexican ethnicity, but to the structure of the program and the social construction of migrant workers and the 'Mexican' (Preibisch \& Encalada, 2010). Employers like these characteristics because they make it easier for workers to be exploited. As for Mexican migrants, they take pride in these features, thinking that they make them 'better' workers than their Caribbean colleagues, and they unintentionally reinforce the employers' prejudices about the Caribbean and Mexican workers, and foster ethnic replacement (Satzewich, 2007).

Despite the exploitative conditions of Mexicans involved in the SAWP, their evaluation of the program is more positive than could be expected. In the study done by Verduzco-Igartúa (2008) in which he interviewed 800 Mexican workers, $36.6 \%$ like 'everything' about the program; $28.2 \%$ like having an employment opportunity; $7.5 \%$ like wages and benefits; $5.9 \%$ like the personal and work experience of being enrolled in 
the program; $5 \%$ like its operation; and $4.2 \%$ like the attitude of their employers. Only $2.2 \%$ ( 8 workers) had a negative opinion. The negative aspects of the program mentioned by the workers are: the trips to Mexico City for enrollment; the medical examination; lack of organization; being away from their families; living conditions on the farms; the weather; Canadian employers' behaviour; low wages and deductions to their salaries. Furthermore, 26 workers (14\%) disliked the attention they were given in Mexican offices and Consulates.

During my interview with the Mexican public servant, while he was aware of the multiple criticisms against the program, he manifested that he did not understand why many Canadians were against it, given that the program offered an opportunity Mexicans did not have in their own country. Furthermore, the official also interpreted the rising numbers of Mexicans as a sign of success. However, he failed in correlating the high participation rates of Mexicans in the program and the situation in rural Mexico: the more successful the program is, the worse the conditions in rural Mexico are.

The workers' positive evaluation of the SAWP (and probably that of the Mexican officer) may be due to the comparison they make between their economic situation in Mexico and their wages in Canada, which are considerably higher. However, it does not mean that the program is practiced within an acceptable framework respectful of the workers' rights, and neither is it a sustainable option for Mexican farmers. 


\section{CHAPTER III: 'Protection' of Nationals Abroad and the Seasonal Agricultural Worker Program}

As a principle of international law, every individual has the right to be protected while in a foreign State. It is the bond of nationality that enables a State to provide assistance to its nationals abroad. Nowadays, the protection of nationals abroad is considered a right to which all humans are entitled as a means for safeguarding their liberty, life, personal security, property, etc. (Uribe, 1997). Accordingly, Mexican seasonal agricultural workers in Canada have the right to be protected by the Mexican State, and the Mexican State has the responsibility to provide adequate protection for them. This section analyzes the diverse national and international mechanisms that regulate the protection of nationals abroad and that are pertinent to the SAWP. It then discusses the limitations that the Mexican State faces when protecting the seasonal workers, and the assistance provided to them by grassroots organizations.

\section{International Framework for the Protection of Nationals Abroad}

The Charter of the United Nations (1945) is an important instrument that outlines the fundamental rights of the individual and thus serves as a tool for the States to protect their nationals abroad. Article 55 of the Charter states that the UN '... shall promote... universal respect for, and observance of, human rights and fundamental freedoms for all without distinction as to race, sex, language and religion'. Article 56 reiterates the commitment of all member States to cooperate with the UN towards the respect of human rights. These articles shed light on the universality of human rights that are inalienable to the person, regardless of the State jurisdiction he or she may be subject to. 
A relevant instrument that serves as a reference for the rights and treatment of migrant workers is the UN International Convention on the Protection of the Rights of all Migrant Workers and Members of their Families of 1990. This convention contains several rights that should be taken into consideration by receiving states and that if implemented, would significantly benefit all seasonal agricultural workers. Some of these rights are: the right to be protected against 'violence, physical injury, threats and intimidation, whether by public officials or by private individuals...' (art.16, par 2); the prohibition of withholding any identity or immigration documents (art.21); the right to seek assistance from the consulates of the immigrants' States of origin, and the obligation of the receiving States to facilitate this right (art. 23); migrant workers and nationals of the receiving State shall be treated equally in terms of employment conditions (art.25 \& art.27); the right to participate and seek the assistance of unions and any other associations that protect their interests and that are established in accordance with law (art.26); right to receive urgent medical care (art.28); the right to be fully informed, either by the receiving or the sending State, about the conditions of their admission (art.37); liberty of movement and freedom to choose their residence (art.39 par.1); the right of workers to participate in the life of their local communities (art.42). Unfortunately, the convention has not been ratified by any of the major migrant-receiving countries.

There are also several international conventions and agreements that regulate the relationship between the States with regard to the protection of their co-nationals on foreign soil and migrant workers specifically. In the SAWP context, the most relevant 
documents are the Vienna Convention on Consular Relations (VCCR) of 1963 and the North American Agreement on Labour Cooperation (NAALC) of $1994^{10}$.

\section{Vienna Convention on Consular Relations of 1963}

An important way in which a State provides protection to its co-nationals abroad is by means of their consular posts. The right of consular protection is initially based on the State's sovereignty and it is a way in which individuals ensure the respect of their rights through the support of their State of nationality when they are abroad.

Before the VCCR, bilateral agreements between receiving and sending States set the rules for consular protection (Uribe, 1997). However, after the Second World War it became imperative to codify international law, and customary rules were the basis for consular relations. These rules codified international practices of consular offices with regard to commercial matters. In their early stages, customary rules only recognized the inviolability of archives and the immunity of consular officers with respect to official acts (Chatterjee, 2007). However, in 1949 the UN considered that consular relations should be universally and uniformly regulated by means of a multilateral treaty and on April $24^{\text {th }}$ 1963 the VCCR came into force (Quigley, Aceves \& Shank, 2009). The VCCR codified existing customary laws and it also implemented new laws. As for the former, they are binding for all States (even those that did not ratify the Convention), as all States must

\footnotetext{
${ }^{10}$ Other important conventions are the International Convention on the Protection of the Rights of All Migrant Workers and Members of their Families, the Convention on Migration for Employment, the Convention concerning Migrations in Abusive Conditions and the Promotion of Equality of Opportunity and Treatment of Migrant Workers. However, since Canada is not a signatory state in any of them, and Mexico has only ratified the first one, they are not applicable to the SAWP.
} 
respect rules of customary origin. However, the rules of conventional origin are only obligatory for the parties to the convention ${ }^{11}$. (Uribe, 1997).

The duties of the consul are not expressly mentioned in the Convention; they vary according to the circumstances of each case. However, Article 5 enumerates some of the most common functions of consular officers relevant to our topic: '...the protection and assistance of co-nationals in the sending State; the protection of the interests of the sending State and of its nationals, both individuals and bodies corporate, in accordance with the laws of the receiving State; the representation or arrangement of appropriate representation for co-nationals before local tribunals and other authorities insofar as the laws of the receiving State permit...'(UN, 1964). This list is not exhaustive and consuls can perform any activities that do not contravene the laws of the receiving State.

The provision of consular protection may vary. The assistance that consuls provide to nationals who find themselves in difficult situations is referred to as 'protection activity', and the employee of the consulate in charge of assisting nationals is the 'protection officer' (Quigley, Aceves, \& Shank, 2009). Assistance is provided in the shape of advice and information on local proceedings; representation before local authorities; contacting interpreters, translators and law firms during judicial procedures; visiting and interviewing nationals that are imprisoned about the treatment and conditions in the facilities; protesting and trying to amend any harm against a national; providing special assistance to people with disabilities, minors, the elderly, or people with limited legal capacity (Uribe, 1997).

\footnotetext{
${ }^{11}$ Examples of customary rules would be the inviolability of the embassy premises and their exemption from taxes. All States must obey these rules, regardless of whether they have ratified the convention or not.
} 
Chapter II of the Convention addresses the 'Facilities, Privileges and Immunities' granted to the consular posts and employees in order to facilitate their performance. Immunity is an important privilege in consular offices, which enables the personnel to perform their job in a better manner. One of the aspects that immunity entails is the confidentiality of all files and documents handled by consular posts, to which the authorities of the receiving States do not have access (Quigley, Aceves, \& Shank, 2009). The confidentiality and flexibility of consular officers to assist their nationals are extremely important for their legal performance, and so is the right to have access to the nationals and communicate with them.

There are two main approaches that the States can take with respect to the right to consular protection. The first one is that it is the obligation of consular officers to provide protection to their nationals. The second approach states that consular protection is a discretionary decision of the State of nationality. Uribe considers that the Mexican State has taken the first approach, since its consular officers must provide assistance for Mexicans dealing with local authorities, and assist co-nationals in detention centres, prisons, hospitals, or any other problematic circumstance (1997). However, this Statement is only true in theory, as in practice the Mexican consulates have huge failures in the protection services they offer.

\section{North American Agreement on Labor Cooperation of 1994}

The governments of Canada, Mexico and the US signed the North American Agreement on Labor Cooperation (NAALC) in 1993 and it entered into force on January $1^{\text {st }}, 1994$. The obligations for each State under the agreement are the improvement and enforcement of their labour laws, the working conditions and the living standards in their 
territory and access to impartial tribunals (Commission for Labor Cooperation, 2002). It is the first agreement that provides a mechanism for governments to ensure workers' rights and to improve their living and working conditions without any interference in the sovereignty of the parties. The Council of Ministries is integrated by the labour ministries of the three countries or their appointees. The agreement provides for the establishment of working groups, intergovernmental consultations, independent evaluations and dispute settlement related to national labour law enforcement (Commission for Labor Cooperation, 1994).

Each country may implement a National Advisory Committee and Governmental Committees to issue recommendations on the improvement and implementation of the Agreement. The parties can also establish consultations with regard to another party's labour law, its enforcement or the conditions of the labor market. If a matter is still unsolved after its evaluation by the Committee, then any of the parties can request the establishment of an Evaluation Committee of Experts (ECE). The agreement also talks about the resolution of disputes through an Arbitration Panel concerning the enforcement of 'occupational safety and health, [and]... minimum wage technical labor standards' (art.27). The Panel acts as a mediator so that the parties compromise to an Action Plan (Commission for Labor Cooperation, 1994).

One of the principles of the NAALC is the protection of migrant workers. The first annex of the agreement mentions that the parties are committed to grant equal legal protection to migrant workers as to nationals and that the Council will promote cooperation agreements in the areas of migrant workers. As stated above and with the objective to protect its farm workers, Mexico has the option to implement an Evaluation 
Committee of Experts to assess Canada's compliance with these regulations and its refusal to allow the unionization of agricultural workers. Unfortunately, this measure has not been taken yet, despite the clear violations of the NAALC committed by Canadian authorities.

A possible explanation for the passiveness of Mexico with regard to requesting the establishment of a Committee to evaluate the conditions of seasonal agricultural workers may be the lack of enforcement of labor laws in Mexico itself. If Mexico decides to demand that Canada enforces certain regulations of the NAALC, it would imply that Mexico has to comply with labour standards as well, and it is unlikely that the country is willing to accept this commitment. Moreover, the Mexican government is aware of the pool of cheap labour that other developing countries represent for Canada. Mexican representatives are afraid that the more complaints there are about unfair treatment to Mexican workers and protection to its co-nationals, the more likely it is that Canadian farmers will cease to employ Mexicans, turning instead to workers from other nations.

\section{Mexican Framework for the Protection of Nationals Abroad}

The most important Mexican law with respect to the protection of nationals abroad is the Law on the Mexican Foreign Service and its regulations. The legislation on the Mexican Foreign Service of 1829 was the first legal document that referred to Mexican consuls and protection of foreign nationals. The subsequent legislations of 1910 and 1923 stated that the primary responsibility of the consular officers was '...the protection of the rights and interests of Mexican nationals' (Warren, 2008, par. 2).

The Ministry of Foreign Affairs regulates the Mexican Foreign Service. Article 1 of the Law of the Mexican Foreign Service (Ley Orgánica del Servicio Exterior 
Mexicano) (1994) defines the Foreign Service as the permanent body of public servants in charge of representing the country abroad and of executing the foreign policy according to the Mexican Constitution. Articles 46 and 47 of the Law of the Mexican Foreign Service authorize direct intervention by Mexican consular officers, in accordance with the laws of the receiving country, to protect the rights of Mexican nationals under international law. Moreover, article 86 of the 'Reglamento' (regulations corresponding to this legislation) establishes the 'primary importance' of protecting the rights of Mexicans abroad. Article 88 requires Mexican consular officers to assist Mexican nationals in their relations with local authorities, visit Mexicans who are detained in prisons, and represent those who cannot personally defend their interests (Ley del Servicio Exterior Mexicano, 1994; Warren, 2008).

In 1981 the Mexican Ministry of Foreign Affairs created the 'consular protection officer', which is a special employee of the Consulate whose sole responsibility is the protection of Mexicans abroad. By 1983, all Consulates in the USA had at least one consular protection officer. The Mexican Consulates in Canada also have one or more consular protection officers. (Arámbula-Romero, 2008; Ministry of Foreign Affairs, 2011).

The Mexican State protecting the SAWP workers

The Ministry of Foreign Affairs is the main actor responsible for the protection of all Mexicans living abroad, and thus for the seasonal agricultural workers. The General Office of Protection to Mexicans Abroad (Dirección General de Protección a Mexicanos en el Exterior) is part of the Under-Secretary for North American Affairs. The latter is responsible for the policy issues regarding protection, and the duty of the former is more 
pragmatic and consists of implementing protection measures for Mexicans, their interests and human rights through the consular posts accredited in different countries (ArámbulaReyes, 2008; personal communication with public servant, June $7^{\text {th }}, 2011$ ). In fact, one of the most important purposes of consular posts is the protection of nationals, which could be considered as the underlying goal of all the other tasks of a consulate (Uribe, 1997).

According to the Mexican public servant interviewed and the literature reviewed, the most frequent cases in which Mexican seasonal workers need the protection of the consulate are derived from accidents in and outside the workplace, deduction of salaries, access to benefits, income tax paperwork, illnesses and insurance, and definite repatriations. In response to these needs, the Consulates perform the following tasks: regular visits to farms; supervising the workers' living and nutrition conditions; being an intermediary between the worker and the employer in any disputes that may arise between them; meeting the workers at the airport at the time of reception; assisting the worker on occupational accidents; ensuring the workers' proper working conditions; taking the workers' calls; providing them with all the necessary legal information; acting on behalf of the workers' rights in case of their absence; assisting them with the insurance paperwork; and their relationship with the provincial and federal government (Embassy of Mexico in Ottawa, 2006).

There are five consular offices of Mexico in Canada located in Calgary, Leamington, Montreal, Toronto, and Vancouver. The consulates in Calgary and Leamington are career consulates, and the rest are consulate-generals. The career consulates are usually smaller and depend on a consulate-general. In terms of consular districts (which outline the jurisdiction of consular posts), the consulate-general in 
Montreal has jurisdiction in Quebec, New Brunswick, Nova Scotia, Newfoundland and Labrador, Prince Edward Island, and Nunavut. The consulate-general in Toronto has jurisdiction in Ontario and Manitoba, and the career consulate in Leamington depends on it. The consulate-general in Vancouver has jurisdiction in British Columbia, Alberta, Saskatchewan, Northwestern Territories and Yukon, and the career consulate in Calgary depends on it. As for protection officers, all consulates have at least one, except for Calgary (Ministry of Foreign Affairs, 2011) ${ }^{12}$. In addition to the services provided in the consular posts, the Mexican Ministry of Foreign Affairs has implemented a program called Consulados Móviles (Mobile Consulates). This program already existed in the United States, and its main objective is for consular officers to visit places far away from consular posts and with a large Mexican community.

With the desire to provide better services for the workers, the consulate-general in Toronto is considering implementing an administrative fund similar to the one that Caribbean workers have. This fund will be integrated with $5 \%$ of the workers' income, which the Consulate considers possible only if the wages increase (Verduzco-Igartúa, 2008). In my opinion, this measure is unsuitable, as the workers already complain about the various deductions to their wages, and almost half of them have a negative opinion about the services and $21 \%$ have not referred to consulates for help (Verduzco-Igartúa, 2008). We must also consider that the protection of Mexicans abroad is a primary responsibility of the State, and thus the workers themselves, who are victims of the poor management of the country's economy and nonetheless contribute to it through their

\footnotetext{
${ }^{2}$ The Consulate in Vancouver has three protection officers. The Consulate in Toronto has only onc, as well as the one in Leamington, and the Consulate in Montrcal has two (Ministry of Foreign Affairs, 2011).
} 
remittances, should not have to subsidize their own protection when they are practically forced out of the country in search of better job opportunities.

Despite the aforementioned arguments, the general belief in Mexico (and in Canada) is that the program is beneficial for both the workers and the employers. This position is also sustained at the institutional level. During a workshop given at the Embassy of Mexico in Ottawa in 2006 by representatives of the Ministry of Foreign Affairs and the Secretariat of Labour, the presenters said that the program was a successful measure for international cooperation and maintenance of migrant workers in a 'regulated, dignifying and organized' way. As already mentioned, when the public servant provided me with statistics on the number of Mexican workers in the program, he argued that the high numbers of the Mexican workers indicated that their protection was adequate. The interpretation that the public servant gave to rising numbers of Mexicans in the program has little to do with the protection services offered to them. Actually, these numbers reflect the deteriorated condition of the country's rural areas and the vulnerability of the workers. Moreover, it is improbable that one of the factors that encourage workers to apply to the program is the protection offered by the Mexican State.

It is also important to acknowledge the existence of measures that Mexican authorities have implemented to improve the protection of the SAWP workers. Since 2010, workers can also evaluate their employers, the living and working conditions, transportation, payments, and deductions. The workers in British Columbia were given a booklet that contained security measures to reduce and avoid risks at the workplace when using chemicals and pesticides (Poder Ejecutivo Federal, 2011). Furthermore, the 
consulate-general in Toronto has an 800 number for workers to contact the office (Verduzco-Igartúa, 2008).

\section{Limitations to the protection of Mexican agricultural workers in the SAWP}

There are several limitations that hinder the capacity of the Mexican State to protect the workers, some of which are inherent in the legal structure of the program itself and others related to the lack of training and insufficient human resources and budget appointed to the Mexican Consulates in Canada, besides the unwillingness of the Mexican government to act on behalf of the workers. After reviewing the literature and conducting the interviews, it is my opinion that the biggest obstacle to the protection of the Mexican SAWP workers is the fear by the Mexican State that the protection it offered would compromise the competitiveness of Mexican workers vis-à-vis other workers from developing countries.

With regard to the limitations that derive from the legal structure of the program, we have seen in earlier sections that the MOU, its Operational Guidelines, and the Agreement for the Employment provide excessive freedom to employers in decisionmaking over aspects such as working hours, days of rest, maintenance of the living quarters, and premature repatriations. Due to the obligatory and binding nature of these documents, the capacity of the consulate is limited. Nonetheless, the public servant denied any legal limitations and mentioned that the Consultoria Juridica (Department of Legal Affairs) of the Ministry of Foreign Affairs considers that there are no legal limits imposed by the MOU or any other documents regarding the operation of the SAWP.

However, the public servant in Mexico did mention two other factors that restrict the performance of the Mexican State: the provincial labour laws and the Canadian 
Privacy Law. With respect to the limits posed by provincial labour laws on working conditions and wage deductions, the public servant argued that Mexico has always been very respectful of domestic laws and acted within the legal limits of the receiving State.

According to the public servant, the Canadian Privacy Law forbids the authorities to disclose any kind of information concerning an individual without his or her previous consent. He mentioned this with respect to workers that are in hospitals and do not give consent for the consulates to find out about their situation. One could question the limits that this law actually poses to the consulate: if we take into consideration that the consulate is the only Mexican institution that is legally entitled to assist Mexican agricultural workers, it seems unlikely that the workers themselves would refuse to disclose personal information to the consulate. Furthermore, Section XI-2 of the Agreement for the Employment (2011) states that:

[t]he WORKER agrees that any personal information held by the Federal Government of Canada and the Government of the Province in which the work is performed may be released to HUMAN RESOURCES AND SKILLS

DEVELOPMENT CANADA, to Citizenship \& Immigration Canada to the GOVERNMENT AGENT, to the Foreign Agricultural Resource Management Service, ... and to the Insurance Company designated by the GOVERNMENT AGENT, so as to facilitate the operation of the Foreign Seasonal Agricultural Workers Program.

This section of the Agreement clearly stipulates that the worker has agreed to release any personal information to the government agent that is related to the operation of the SAWP. Therefore, when a worker is injured, the consulate should be notified 
immediately in order to start the paperwork for his or her repatriation, insurance, or any other procedure related to the worker's participation in the program.

Concerning the limitations derived from the deficiencies of the Ministry of Foreign Affairs, in spite of the five Mexican consulates and the Consulados Móvlies program (Mobile Consulates Program), consulates fail to reach some of the workers due to the large areas in which the consulate has jurisdiction, the scattered locations of the farms, and the limitations in human and monetary resources. Basok (2011) also argues that the consulates do not employ enough staff to visit the farms, and do not provide the workers with the help they need to claim their rights and benefits. The public servant interviewed commented that the Ministry of Foreign Affairs annually approves a budget for the protection of Mexicans living abroad, and that there is a special allocation for the SAWP workers, but he refused to give concrete numbers.

Unfortunately, the capacity and budget of the consulates do not correspond to migrant workers who need their services. The field research conducted by VerduzcoIgartúa (2008) shows that nearly 3,000 workers per season need consular assistance, and that the massive numbers of seasonal workers has surpassed the human and space capacity of the Mexican Consulates. This is supported by his statistics that show that less than one quarter of the workers interviewed considered that the services received by the consulate were proper, $44.4 \%$ think that the Consulate does not represent them properly, and $21 \%$ did not reply because they had not used any consular services (VerduzcoIgartúa, 2008).

Even in Mexico, there are misconceptions and discriminatory attitudes against the rural population that, unfortunately, are reflected in the institutional responses with 
respect to the protection of the agricultural workers. For instance, the public servant thinks that farmers prefer Mexican workers because they are very 'adaptable'. The public servant did not seem to be aware of the vulnerabilities of the Mexicans due to discriminatory stereotypes, economic conditions, and lack of fluency in English, which are actually important assets that the employers take into account when choosing the source country of the workers. By using the word 'adaptable', he perpetuated the misconception that Mexicans are more suitable for agriculture (and low-skilled jobs in general) as an inherent part of their ethnicity, corroborating the idea of 'Mexicanness' discussed in earlier sections of the paper.

Despite the flow of Mexican workers to Canada and the fact that the program is now 37 years old, Mexico still regards the United States as the main arena in which protection to co-nationals takes place, and has made little efforts to implement protection programs designed specifically for farm workers within the SAWP. Most of the protection activities of the consulates in Canada do not differ from the programs implemented in the United States (which are also inefficient), disregarding the difference between the migration experiences of the Mexican rural population in Canada under the SAWP and in the United States.

With respect to the dilemma faced by the Mexican State regarding the protection of workers and their competitiveness, Binford puts this situation into perspective arguing that '...consular representatives are under pressure to maintain good relationships with...growers, who have the right to choose the source countries from which they draw their workers. The more vigorously the Consulate advocates on behalf of Mexican migrant workers, the greater the likelihood that growers will opt for Caribbeans rather 
than Mexicans in the future.' (2009, p.510) Lowe (2008) supports this argument by commenting on one case where the consulate of Mexico blacklisted a particular farm that mistreated the workers, and thus the Mexicans working on that farm lost their jobs. Instead of forbidding that particular grower to hire any workers at all, the farm stopped hiring Mexicans for the following season and hired Guatemalans instead under the Temporary Foreign Worker Program, which is less regulated.

The pressure that Mexican Consulates have to preserve seasonal jobs has led the Consulates to be unresponsive to the needs of workers. Basok's research shows that less than half of the workers that reported mistreatment by their employers sought help from the Consulate, and 15 out of 34 workers that used consular services claimed that they did not receive adequate attention or that they were ignored, and that 'the consulate resolves nothing' (p.510, 2009). Basok (2009) considers that the Consulate chose a 'negotiation strategy' over an 'advocacy strategy', which has led the workers to believe that they have no support from the consulate to claim their rights.

In personal communication with the activist, she corroborated the inefficiency of the consular services arguing that the consulates do not provide effective assistance to the workers. She brought to my attention the case of Laura, a female Mexican worker in Ontario who was harassed by a consular officer who wanted her to sign forms in which she gave up the right to treatment and benefits in Canada after having an accident in the workplace. The officer also wanted her immediate repatriation to Puebla, Mexico.

More recently, on May 2011, the consulate of Mexico in Vancouver was accused of blacklisting two workers who were union sympathizers and had successfully unionized. The consular officer did not want them to return to Canada the following 
season and warned other Mexican workers to stop visiting union support centres. The United Food and Commercial Workers (UFCW) filed charges against the consulate and the Mexican Senate demanded an explanation from the Ministry of Foreign Affairs (UFCW, 2011; PRI, 2011), which has not responded to this date.

Nonetheless, the public servant argues that 'the protection' does not interfere with the hiring of Mexican workers, and that the employers are generally satisfied with the program. The public servant considers that the employers' satisfaction is related to the adequate intervention of the Consulate. I would differ with the public servant's opinion, as the more exploitable and unprotected the workers are, the more profitable it is to hire them, and thus the more satisfied some farmers are. The satisfaction of the employers is also due to the fact that consular officers often side with them instead of with the workers to save the workers' jobs (Sook Lee, 2003).

The fact that farmers are comfortable with Mexican workers could actually reflect the poor intervention of the consular officers who, due to the exigencies from the Ministry of Foreign Affairs and the Secretariat of Labour, feel compelled to maintain the high hiring rates, even at the expense of violations of the workers' rights. In this respect, the vested interest that the Mexican government has in the success of the SAWP, and its direct work with FARMS makes it difficult for consulates to actually act on behalf of the workers (Preibisch, 2004).

The public servant interviewed also mentioned that there are labour unions, which demand that the Mexican government should intensify its activities with regard to the protection of seasonal workers. However, the public servant believes that the protection framework is adequate, since the farmers are content and labour migration takes place in 
a legal and organized manner. At no time during the interview did the public servant mention anything about the workers' perspective of the consulate's performance.

Furthermore, he mentioned that the documentary $\mathrm{El} \mathrm{Contrato}^{13}$ was edited, meaning that it did not reflect the reality about the performance of Mexican consular officers.

However, at the end of the conversation, the public servant admitted that 'there is still a lot to be done' with regard to the program and the protection of the workers, but he reiterated that the SAWP was a good opportunity for Mexican farmers to have a better income, acknowledging that the current situation in rural Mexico did not leave the farmers with any more options.

\section{Grassroots organizations and unions as an alternative for the protection of} Mexican agricultural workers

Migrant workers have found enormous support in community centres, grassroots organizations and unions such as Justicia 4 Migrant Workers, Dignidad Obrera Agrícola Migrante (DOAM), UFCW, etc. Due to the community-based nature of these organizations and the fact that some were founded by migrant workers themselves (such as DOAM), they know the real needs of the workers and have a better understanding of the obstacles they experience while in Canada. Since these organizations do not pursue any political aims or compromises, they are able to support the workers in a more appropriate way than institutional channels such as consulates and government offices (both from Mexico and Canada).

\footnotetext{
${ }^{13}$ El Contrato is a documentary filmed in Leamington that shows the living and working conditions of Mexican seasonal agricultural workers, as well as their interaction with the Consulate.
} 
Another advantage of these associations is that they are in constant communication with the workers, either through centres they have established in locations with a considerable number of migrant workers ${ }^{14}$ or through visits to the farms. Furthermore, they have the ability to organize resistance movements with the workers, such as the "Pilgrimage to Freedom"' ${ }^{15}$. According to the activist I interviewed, they do not impose their own ideologies on the workers and neither do they tell them how they should organize. On the contrary, they support the workers' ideas and help them build their own resistance movements based on what the workers want (personal communication with activist, June $25^{\text {th }}, 2011$ ).

Grassroots organizations have also been able to constitute a social network of allies that can assist workers with particular needs, such as referrals for legal firms and hospitals that provide pro bono services. The activist I interviewed commented that her NGO organizes fundraising events and receives in-kind contributions to help immigrants. Other activities consist of acting as a mediator between the worker and the employer, supervising the living and working conditions of the workers and bringing their complaints to the employer's attention; helping the workers organize and resist against exploitative conditions; supporting workers' initiatives such as DOAM; assisting the workers during repatriation and helping them get legal assistance; and informing migrant workers about any important news affecting their status and working conditions in Canada.

\footnotetext{
14 The UFCW has established Migrant Agricultural Worker Support Centres in Leamington, Bradford, Simcoe, Virgil, Saint Rémi, Abbotsford, Portage la Prairic, and Kelowna (Agriculturc Workers Alliance, n.d.)

is The 'Pilgrimage to Freedom' was coordinated by Justicia 4 Migrant Workers. It was a march canied out by migrant workers, allies and activists from Leamington to Windsor during Thanksgiving Day in 2010 . The objective was to shed light on the reality of food processing in Ontario and the working conditions of migrant workers (Justicia 4 Migrant Workers, n.d.).
} 
The activist also commented on the relationship that she has with the workers. Through regular visits to farms, she has established friendships with the workers, and has even traveled to Mexico to get to know the workers' families and spent holidays with them. This type of activism transcends the working sphere and strengthens the trust that workers have in grassroots organizations, eliminating the power relationships, and helping activists gain in-depth knowledge of the workers' experiences in Canada and designing better strategies to help them.

The public servant I interviewed did not seem to be acquainted with grassroots organizations. However, he suggested that a survey should be conducted on the farms, asking Mexican workers their opinion concerning the services offered by the consulate, and that the latter should foster and improve relationships with pro-immigrant NGOs. I agree with the public servant, as grassroots organizations can be powerful allies for the consulates in terms of helping them gather workers, facilitate informative workshops, lend facilities for meetings, and inform the consular officers about the real living and working conditions of the Mexican workers. However, grassroots organizations are very critical of the performance of the Mexican consulates, and thus establishing a working relationship with them is a huge challenge that implies a shift in the attitude of consular officers with regard to workers, changing from a 'negotiation strategy' to an 'advocacy strategy'. 


\section{Discussion}

Following the critical social research method, I reviewed the relevant literature and interviewed two participants that are key actors in the SAWP. This allowed me to know the academic research and perspectives on the program as well as two divergent points of view. My findings provided me with the basis to analyze both sides of the spectrum and give a better opinion of the performance of the Mexican State with regard to the protection of the seasonal agricultural workers.

I was able to interview a Mexican public servant in Mexico City and an activist in Canada. Unfortunately, the consular officer refused to schedule an interview. It is my belief that the officer's refusal was connected to the recent events related to the Mexican consulate in Vancouver, which blacklisted some workers that were affiliated with unions, trying to impede their reenrollment in the program. Mexican officials involved in the SAWP are aware of the criticisms of the program and thus avoid giving interviews about it.

During my interview with the public servant, he showed defensive behaviour, and at the beginning gave institutional responses supporting the program. On the one hand, the public servant provided information relevant to the standpoint of the State with regard to the SAWP and the protection of the workers' rights. On the other hand, the activist presented a personal perspective on the lack of support that the Mexican State offers to the workers, based on her experience as a grassroots organizer. Towards the end, the public servant acknowledged that 'there is still a lot of work to be done' regarding the program and the protection of the Mexican workers. 
With regard to the findings, the situation in rural Mexico has been unfavourable for a long time, and unfortunately there is no indication that this situation will change. The attitude of the Mexican federal government shows helplessness and resignation to keep on exporting its labour force to capitalist economies like the American and the Canadian ones. Furthermore, neo-liberal policies such as the signing of free trade agreements like the General Agreement on Tariffs and Trades (GATT) and NAFTA have deteriorated the conditions in rural Mexico even more. Only a few people in rural areas own ejidos ${ }^{16}$, and even those who do, have little incentive to invest in their lands as their fields are small, and they lack proper infrastructure.

There is no doubt that the SAWP is beneficial for Canadian agriculture, and unless the economic situation in rural Mexico changes, it is indispensable for the Mexican economy. Most of the workers participating in the program have been farm labourers in Mexico and Canadian wages exceed national wages, plus they get to work year-round in Canada. Moreover, the workers have improved their economic situation, their children are able to go to school, the program has prevented irregular migration (which is a very positive thing for the Mexican government, as it is easier to keep track of its population abroad), and the administrative costs to Mexico are not overwhelming (Verduzco-Igartúa, 2008).

The inclusion of Mexico in the SAWP has also represented enormous disadvantages for the workers. It has affected their personal and family lives and exposed them to dangerous and exploitative working conditions and discrimination, while slightly improving their livelihood. The large pool of cheap labour available to Canada represents

\footnotetext{
${ }^{16}$ Similar to the ownership of common land
} 
a reduction in the bargaining power not only for Mexicans, but also for all the other developing countries involved in this race to the bottom. Due to the number of foreign workers willing to participate in Canadian agriculture, the Memorandum of Understanding and the Agreement for the Employment between Canada and Mexico are becoming less favourable to Mexicans every year. In addition, employers often violate the regulations, but receive no real sanctions.

In order to address the first research question which concerns the workers' needs that are not addressed by the consulate, I argue that these needs derive mainly from the violations to the Agreement for the Employment and provincial laws with regard to compensations, accidents in and outside the workplace, illnesses, unfair definite repatriations, insurance and tax return paperwork, and the rights and benefits that workers are unable to claim due to their lack of status or knowledge of the official languages.

Not only does the Agreement for the Employment institutionalize exploitation, but the growers also commit violations to the already exploitative conditions. Furthermore, the Agreement contains several stipulations left intentionally 'unspecified', so that employers can interpret them at their convenience. Therefore, Mexican workers are in need of institutions that can grant them the protection they need when working abroad under such vulnerable conditions. For the purpose of protecting nationals abroad, there are several international agreements that regulate relations between the receiving and the sending State. In the SAWP context, I consider that the most important international instruments are the VCCR of 1964 and the NAALC of 1994. The former sets the regulatory framework under which consular relations will take place, and the latter refers to standardized labour laws that Mexico, the United States, and Canada have 
committed to enforce. In addition to these international instruments, Mexico has domestic laws that stipulate the obligation of the State to safeguard the interests of its nationals abroad, the most important being the Law on the Mexican Foreign Service.

In spite of national and international regulations providing for the protection of co-nationals abroad, the Mexican State has not utilized the legal resources provided by the NAALC, such as requesting the implementation of Advisory and Evaluation Committees to assess Canada's compliance with the objectives of the agreement. Mexico has also failed in complying with the regulation stated in the VCCR with regard to 'the protection of the interest of the sending State and of its nationals...' (1963, art.5). Furthermore, the State has also disregarded the Law of the Foreign Service, which authorizes the direct intervention of the Foreign Service members to protect the rights and interests of Mexicans abroad under international laws.

Regarding the research question, Why are the workers' needs in Canada not being addressed?, the Mexican State is unable to address the workers' needs due to various limitations that derive from three main factors:

1.Legal and policy limitations: The MOU, the Operational Guidelines, and the Agreement for the Employment leave little space for Mexican public servants to file a complaint for non-compliance with the regulations of the SAWP. These documents institutionalize unfree labour and grant the employer enormous control over the workers.

2.Inadequate protection measures: Consular posts are the most important instrument that States have for protecting their nationals abroad. In spite of the fact that there are five consular posts that Mexico has in Canada, the large number of agricultural workers surpasses their budget and human capacity. The personnel does not receive the 
proper training to deal with the specific needs of the workers, and the Ministry of Foreign Affairs has not developed any spccial programs to address the specific needs of seasonal agricultural workers, other than visits to the farms, which are not carried out as often as needed.

The public servant I interviewed corroborated the general belief that the program is a success, and perpetuated the idea of Mexicans being 'adaptable' to agricultural work. However, he did acknowledge that as long as the conditions in rural Mexico remain unfavourable, this program represents perhaps the best job opportunity that many Mexican farmers have. Bureaucrats in the Ministry of Foreign Affairs, whether in the central headquarters or at consular posts, must realize that, albeit needed, neither the program nor the protection of workers is a 'success' and the SAWP is not a sustainable option. Since the Ministry's sole responsibility with regard to the SAWP is the protection of the Mexican workers and it has no control over Mexico's participation in the program, it must try to improve the services delivered to the workers. But this is not an easy matter, as Mexican workers are in a race to the bottom against the other developing countries and the more protection the workers have, the less competitive they are.

3. Competitiveness vs. protection: I consider this to be the most important and biggest limitation that the Mexican State faces in protection of its nationals. The Ministry of Foreign Affairs must find a balance between the 'protection' it offers to the workers and how it may affect the workers' jobs. With the extension of the Foreign Worker Program to agriculture, every country with a surplus of 'low-skilled' workers can join the program and work in Canadian farms and since employers can choose the source country of their workers, the bargaining power of all the source countries involved decreases. The 
rationale of the consulates in order to protect the workers' rights and keep employers interested in hiring Mexicans has been to negotiate rather than to advocate for the workers' well-being, incurring practices that leave the workers in even more vulnerable situations.

The Vienna Convention and the Law of the Mexican Foreign Service stipulate that consular posts and members of the Foreign Service must protect the interests of both the State they are representing and their citizens abroad. However, the adequate protection of the SAWP workers can sometimes compromise the State's interests. Since the SAWP represents constant remittances for the Mexican government as well as a source of employment, the Ministry of Foreign Affairs is under pressure to maintain as many Mexicans as possible participating in the program, even if it means disregarding abuses, exploitation, discrimination and violations to the workers' human rights.

As I have argued, consular protection is not a factor that workers even take into consideration when applying for the SAWP. In fact, a considerable number of workers think that the consulates do not represent them properly but they still sign up. Therefore, the Ministry has given priority to the protection of the interests of the State over the protection of the workers. For this situation to revert, there needs to be a change in rural Mexico and the national agriculture needs to be developed, which is not an uncomplicated issue.

The last topic discussed in the paper is the role of grassroots organizations in the protection of Mexican migrant workers. Indeed, these organizations are able to assist and make up for the State's deficiencies in assisting the workers. Their community-based nature, the fact that they do not pursue any political interest, and that they are not 
constrained by any protocols allow them to organize resistance movements and help workers in a more humane and appropriate way. Although the members of these organizations could potentially be very good allies of the Mexican consulates, their role as activists and their relationships with the workers would be compromised if they were to partner with institutions that do not have a good reputation among the workers. Therefore, unless the Mexican State implements more effective protection activities, it is unlikely that pro-immigrant NGOs will side with them in the fight for migrant rights.

To conclude, the Mexican State is not complying with its responsibility to protect the seasonal agricultural workers in Canada. There are legal boundaries, as well as deficiencies in the protection activities carried out by the public servants at the Ministry of Foreign Affairs and the consulates that impede the proper protection of Mexican workers. Nonetheless, the most important limitation is the little bargaining power that the Mexican State has to negotiate the living and working conditions of its workers in Canada, given the priority it places on the need to find employment for its rural population. The Mexican government must improve the conditions of the country's rural areas in order to be able to demand better treatment for its workers and offer them adequate protection. Slight developments in Mexican agriculture will lead to small but significant changes in the conditions of the Agreement for the Employment with Mexico, which would drastically improve in favour of the workers, and the program would really be an 'alternative' to employment, rather than a necessity. 


\section{Appendices}

\section{Appendix I- Interview Guide}

\section{A) Interview questions for the employee of the consulate-general of Mexico in}

\section{Toronto}

1. How many seasonal agricultural foreign workers are there in the provinces of Ontario and Manitoba?

2. What are the services offered by the Consulate to assist Seasonal Agricultural Workers?

3. How many employees are in charge of assisting the seasonal agricultural workers?

4. How much of your budget is allocated to the assistance of the seasonal agricultural workers?

5. What are some of the issues for which the workers turn to the Consulate for help?

6.Do you keep records of how many workers you assist on a timely basis? If so, would you share this information?

7. Which services offered by the Consulate are seasonal agricultural workers more likely to use?

8. Are there any situations in which the workers cannot seek the Consulate's protection? If so, which situations are these and why can't they refer to the Consulate? 
9. In your opinion, does the Memorandum of Understanding between Mexico and Canada limit the capacity of the Consulate to assist the seasonal agricultural workers? If so, in which way?

10. In your opinion, is there any way in which you could improve the services offered to seasonal agricultural workers?

11. Is there anything else you would like to add?

B) Interview questions for the Ministry of Foreign Affairs in Mexico

1. What are the services offered by the Consulates to assist Seasonal Agricultural Workers in Canada?

2. On average how many employees are there involved with the Seasonal Agricultural Worker Program?

3. How much of your budget is allocated to the Consulates for the assistance of the seasonal agricultural workers?

4. Which services offered by the Ministry of Foreign Affairs (through the department of Consular Protection) are seasonal agricultural workers more likely to use?

5. What are some of the issues for which the workers turn to the Ministry of Foreign Affairs in Mexico?

6. Are there any situations in which the workers cannot seek the assistance of the Ministry of Foreign Affairs? If so, which situations are these and why can't they refer to the Ministry? 
7. In your opinion, does the Memorandum of Understanding between Mexico and Canada limit the capacity of the Ministry to assist the seasonal agricultural workers? If so, in which way?

8. In your opinion, is there any way in which the Ministry could improve the services offered to seasonal agricultural workers?

9. Is there anything else you would like to add?

\section{C) Interview questions for the activist}

1. How long have you been working with seasonal agricultural workers from Mexico?

2. What kind of assistance does Justicia offer to seasonal agricultural workers?

3. Do you keep records of how many workers the organization assists on a timely basis, and how many of them are Mexican? If so, would you share this information?

4. Do you think that Mexican agricultural workers face different challenges than seasonal workers from other nationalities?

5. Are you familiar with any of the services offered to the agricultural workers by the consulate-general of Mexico in Toronto?

6. In your opinion, does the Consulate provide effective assistance to the seasonal agricultural workers? Can you provide any examples?

7. If the person answers NO in the previous question, then this question will be asked: Do you think that the fact that Mexican seasonal agricultural workers often seek help in 
grassroots organizations like Justicia 4 Migrant Workers, is partly due to the lack of adequate assistance from their Consulate?

8. Do you have any suggestions on how the Consulate may improve its services to better assist the seasonal agricultural workers?

Appendix II- Table of Acronyms

\begin{tabular}{|l|l|}
\hline CIC & Citizenship and Immigration Canada \\
\hline DOAM & Dignidad Obrera Agricola Migrante \\
\hline ECE & Evaluation Committee of Experts \\
\hline EI & Employment Insurance \\
\hline FARMS & $\begin{array}{l}\text { Foreign Agricultural Resource } \\
\text { Management Service }\end{array}$ \\
\hline GATT & General Agreement on Tariffs and Trade \\
\hline HRSDC & $\begin{array}{l}\text { Human Resources and Skills Development } \\
\text { Canada }\end{array}$ \\
\hline ILO & International Labor Organization \\
\hline LLSO & Local Labour Service Office \\
\hline LMO & Labour Market Opinion \\
\hline MOU & Memorandum of Understanding \\
\hline NAALC & $\begin{array}{l}\text { North American Agreement on Labor } \\
\text { Cooperation }\end{array}$ \\
\hline NAFTA & North American Free Trade Agreement \\
\hline NGO & Non-governmental Organization \\
\hline NOC & National Occupational Classification \\
\hline OFL & Ontario Federation of Labour \\
\hline SAWP & $\begin{array}{l}\text { Seasonal Agricultural Foreign Worker } \\
\text { Program }\end{array}$ \\
\hline
\end{tabular}




\begin{tabular}{|l|l|}
\hline UFCW & United Food and Commercial Workers \\
\hline UN & United Nations \\
\hline VCCR & Vienna Convention on Consular Relations \\
\hline
\end{tabular}




\section{References}

Agriculture Workers Alliance (n.d.). History of Agricultural Workers in Canada. Retrieved from: http://awa-ata.ca/en/about/history-of-agricultural-workers-in-canada/

Alba, F. (2008). The Mexican Economy and the Mexico-U.S. Migration: A Macro Perspective. In A. Escobar-Latapí \& S.F. Martin (Eds.), Mexico-U.S. Migration Management. United States: Lexington Books.

Arámbula-Reyes, A. (2008). Protección Consular a los Mexicanos en el Exterior. Distrito Federal: Centro de Documentación, Información y Análisis. Cámara de Diputados LX Legislatura. Retrieved on July $12^{\text {th }}$, 2011 from: www.diputados.gob.mx/cedia/sia/spe/SPE-ISS-15-08.pdf

Basok, T. (2002). Tortillas and Tomatoes. Transmigrant Mexican Harvesters in Canada. Canada: McGill-Queen's.

Basok, T (2004). Post-national Citizenship, Social Exclusion and Migrants' Rights: Mexican Seasonal Workers in Canada. Citizenship Studies, 8(1), 47-64

Binford, L. (2006). The Seasonal Agricultural Worker Program and Mexican Development. Ottawa: Canadian Foundation for the Americas.

Binford, L. (2009). From Fields of Power to Fields of Sweat: The Dual Process of Constructing Temporary Migrant Labour in Mexico and Canada. Third World Quarterly, 30 (3) 503-517.

Canadian Charter of Rights and Freedoms, Part I of the Constitution Act, 1982 being Schedule B to the Canada Act 1982 (U.K.), 1982, c. 11.

Cámara de Diputados del H. Congreso de la Unión (1994). Ley del Servicio Exterior Mexicano. Retrieved on July $12^{\text {th }}, 2011$ from: http://www.sre.gob.mx/images/stories/marconormativodoc/ley02.pdf

Chang, Y. (Director). (2001). Earth to Mouth (Documentary). Montreal: National Film Board of Canada.

Chatterjee, C. (2007). International Law and Diplomacy. London and New York: Routledge

Citizenship and Immigration Canada (2010a). Facts and figures 2009 - Immigration Overview: Permanent and temporary residents. Total entries of foreign workers by source country. Retrieved on February $26^{\text {th }} 2011$ from: http://www.cic.gc.ca/english/resources/statistics/facts $2009 /$ temporary/07.asp

Citizenship and Immigration Canada (2010b). Temporary Foreign Worker Program. 
Labour Market Opinion (LMO) Statistics. Annual Statistics 2006-2009. Retrieved on February $26^{\text {th }}, 2011$ from:

http://www.hrsdc.gc.ca/eng/workplaceskills/foreign_workers/stats/annual/table10a.sht $\mathrm{ml}$

Consejo Nacional Agropecuario (2008). Efectos del TLCAN sobre el campo mexicano. Retrieved on August $27^{\text {th }}, 2011$ from: www.coparmex.org.mx/upload/bibVirtualDocs/8 entorno julio 08.pdf

Consulate General of Mexico in Toronto (2010). Accessed on June $27^{\text {th }}, 2011$ from: http://www.consulmex.com/eng/

Commission for Labor Cooperation (2002). Protection of Migrant Agricultural Workers in Canada, Mexico, and the United States. Washington: Secretariat of the Commission for Labor Cooperation.

Commission for Labor Cooperation (1994). The North American Agreement on Labor Cooperation. Washington: Secretariat of the Commission for Labor Cooperation.

De Genova, N. \& Peutz, N. (2010). (Eds.). The Deportation Regime: sovereignty, space, and the freedom of movement. United States: Duke University Press.

Delgado-Bailón, A. (2008) Funcionamiento del Programa de Trabajadores Agrícolas Temporales México-Canadá. (Unpublished dissertation). Universidad de Las Américas, Puebla, Puebla.

Diego-Qunitana, R. (2004). El ejercicio profesional agronómico en México y los enfoques epistemológicos de las ciencias naturales y sociales. In L. LlanosHernández, M.A. Goytia-Jiménez, \& A.A. Ramos-Pérez (Eds.), Enfoques metodológicos criticos e investigación en ciencias sociales (pp. 61-80). Distrito Federal: Plaza y Valdéz Editores.

Dirección de Movilidad Laboral de la Coordinación General del Servicio Nacional de Empleo, May, 2011. Programa de Trabajadores Agrícolas Temporales MéxicoCanadá. Reporte de acciones de vinculación laboral, cifras al mes de mayo de 2011. Retrieved on July $2^{\text {nd }}, 2011$ from: www.stps.gob.mx/.../Prog\%20de\%20Trab\%20Agric\%20Migr\%20Temp\%20MC.xls

Embassy of Mexico in Ottawa (2006). Programa de Trabajadores Agrícolas Temporales México-Canadá y la Asistencia Brindada por los Consulados a los Trabajadores Mexicanos en el Exterior. Taller 'Trabajadores migrantes: Protección de sus derechos laborales y programas del mercado de trabajo'. Retrieved on July $2^{\text {nd }}, 2011$ from: www.sedi.oas.org/ddse/migrantes/contenidos/..\%20Nov...Mexico_ESP.ppt

Fitzgerald, D. (2009). A Nation of Emigrants: How Mexico Manages its Migration. Los Angeles: University of California Press. 
González-Amador, R. (2009, September, 18). Transnacionales controlan 10\% de alimentos producidos en México. La Jornada. Retrieved on August, 26th, 2011 from: http:/www.jornada.unam.mx/2009/09/18/economia/022n1eco

George, U. \& Young, J (2006). Immigration to Canada: The Case of Mexicans. Joint Centre of Excellence for Research on Immigration and Settlement. Retrieved on February, $28^{\text {th }}, 2011$ from: www.eliamep.gr/wpcontent $/ . . . / \mathrm{en} / . . . /$ migsys_canada mexicans july 06.pdf

Human Resources and Skills Development Canada (2010). Temporary Foreign Worker Program. Labour Market Opinion (LMO) Statistics. Foreword. Seasonal Agricultural Worker Program. Retrieved on February $26^{\text {th }}, 2011$ from:

http://www.hrsdc.gc.ca/eng/workplaceskills/foreign_workers/stats/annual/foreword sa wp.shtml

Human Resources and Skills Development Canada (2011a). Temporary Foreign Worker Program. Hiring Foreign Agricultural Workers in Canada. Retrieved on June 1 $7^{\text {th }}$, 2011 from: http://www.hrsdc.gc.ca/eng/workplaceskills/foreign workers/sawp.shtml

Human Resources and Skills Development Canada (2011b). Agreement for the Employment in Canada of Seasonal Agricultural Workers from Mexico-2011. Retrieved on June, $17^{\text {th }}, 2011$ from: http://www.hrsdc.gc.ca/eng/workplaceskills/foreign_workers/sawp_contracts.shtml\#c 01

Isa, J. (1998). Testing the NAALC's Dispute Resolution System: A Case Study. Journal of Gender, Social Policy and the Law, 7, 179-217.

Justicia for Migrant Workers \& Center for Spanish-Speaking People, CSSP (n.d). Migrant Workers and Employment Insurance. What You Should Know. The Law Foundation of Ontario, Ontario.

King-Chigbo, K \& Basmajian, S (Producers), \& Sook Lee, M. (Director). (2003). El Contrato (Documentary). Montreal: National Film Board of Canada.

Lowe, S. (2007). Plus ça change?- A comparative Analysis of the Seasonal Agricultural Workers Program and the Pilot Foreign Worker Program for Farm Workers in Quebec (Unpublished dissertation). Ryerson University, Toronto.

Lutz, B. \& Vizcarra-Bordi, I. (2007). Entre el Metate y el Sueño Canadiense:

Representaciones Femeninas Mazahuas sobre la Migración Contractual Transnacional. Amérique Latine Histoire et Memoire, Les Cahiers ALHIM 14. Retrieved on February $22^{\text {nd }}, 2011$ from: http://alhim.revues.org/index $2592 . \mathrm{html}$ 
Mackinlay-Grohmann. (1993). Las reformas de 1992 a la legislación agraria. El fin de la Reforma Agraeia mexicana y la privatización del ejido. Polis. Investigación y Análisis Sociopolitico y Psicosocial, year 1993, 99-127

Ministry of Foreign Affairs (2011). Consulados de México en el Exterior. Retrieved on July $10^{\text {th }}, 2011$ from: http://sre.gob.mx/index.php/representaciones/consulados-demexico-en-cl-exterior

National Union of Public and Federal Employees (2011). Supreme Court of Canada turns its back on farm workers. Retrieved on August $26^{\text {th }}, 2011$ from: http://www.nupge.ca/content/4243/supreme-court-canada-turns-its-back-farm-workers

Neuman, W.L (2003). Social Research Methods. Qualitative and Quantitative Approaches. Boston: University of Wisconsin at Whitewatter.

Partido Revolucionario Intitucional (PRI). (2011). Puntos de Acuerdo. Retrieved on July $24^{\text {th }}, 2011$ from: http://www.diputadospri.org.mx/res-

01/oldsite/prensa.php?accion=texto\&noticia $=6005$

Pastor, R.A (2010). Should Canada, Mexico, and the United States Replace Two

Dysfunctional Bilateral Relationships with a North American Community? Edmonton: University of Alberta.

Poder Ejecutivo Federal (2002). Reglamento de La Ley del Servicio Exterior Mexicano. Retrieved on February $26^{\text {th }}, 2011$ from:

http://dgctc.sre.gob.mx/pdf/ReglamentoLeyScrvicioExterior.pdf

Preibisch, K. (2011). Canada's highest court rules against farm workers. Focal. Retrieved on August $26^{\text {th }}, 2011$ from: http://www.focal.ca/publications/focalpoint/457-june2011-kerry-preibisch

Preibisch, K. (2004). Migrant Agricultural Workers and Processes of Social Inclusion in Rural Canada: Encuentros and Desencuentros. Canadian Journal of Latin American and Caribbean Studies, 29 (57-58), 203-239.

Preibisch, K. \& Binford, L. (2007). Interrogating racialized global labour supply: an exploration of the ethnic replacement of foreign agricultural workers in Canada. Canadian Review of Sociology and Anthropology, 44 (1), 5-36.

Preibisch, K. \& Encalada, E. (2010). The Other Side of El Otro Lado. Journal of Women in Culture \& Society, 35(2), 289-316.

Preibisch, K. \& Santamaria, L.H. (2006). Engendering Labour Migration: The Case of Foreign Workers in Canadian Agriculture. In E. Tastoglou \& A. Dobrowolsky (Eds.), Women Migration and Citizenship: Making Local, National and Transnational Connections. Canada: Ashgate. 
Poder Ejecutivo Federal (2011). Cuarto Informe de Ejecución del Plan Nacional de Desarrollo 2007-2012. Retrieved on February 22 ${ }^{\text {nd }}, 2011$ from:

www.indaabin.gob.mx/leyinfo/informes/informes.pdf

Quigley, J, Aceves, W.J \& Shank, S.A. (2009). The Law of Consular Access. A documentary guide. London and New York: Routledge

Roffe-Gutman, M. \& Lapalme, A. (2009). Una mano de obra barata: los trabajadores agrícolas temporales en Québec. Focal. Retreived on June $2^{\text {nd }}$, 2011 from: http://www.focal.ca/publications/focalpoint/351-november-2010-mayra-roffe-gutmany-annie-lapalme-sp

Satzewich, V. (2007). Business or Bureaucratic Dominance in Immigration Policy Making in Canada: Why Was Mexico Included in the Caribbean Seasonal Agricultural Workers Program in 1974? International Migration and Integration, 8 (1), 255-275.

Seiler, M.R (n.d.) Human Condition in the Critical Theory Tradition. Retrieved on July $16^{\text {th }}, 2011$ from: http://people.ucalgary.ca/ rseiler/critical.htm

Stalker, P. (1994). The Work of Strangers: A Survey of International Labour Migration. Geneva: International Labour Office.

United Food and Commercial Workers (UFCW). (2011). Charges allege Mexico Consulate blacklisted unionized Mexican migrant workers in B.C. Retrieved on July $25^{\text {th }}, 2011$ from:

http://www.ufcw.ca/index.php?option=com_content\&view=article $\&$ id $=2353 \% 3$ Adidmexican-consulate-try-to-bust-a-bc-union-of-mexican-migrantworkers \&catid $=5 \% 3$ Amedia-releases \&Itemid $=6 \&$ lang $=$ en

United Nations (1954). Charter of the United Nations. Retrieved on July $9^{\text {th }}, 2011$ from: http://www.un.org/en/documents/charter/chapter9.shtml

United Nations (1949). Convention on Migration for Employment. Retrieved on February $26^{\text {th }}, 2011$ from: http://www.ilo.org/ilolex/cgi-lex/convde.pl?C097.

United Nations (1990). International Convention on the Protection of the Rights of All Migrant Workers and Members of their Families. Retrieved on August, $26^{\text {th }}, 2011$ from: http:/www2.ohchr.org/english/law/cmw.htm

United Nations (1948). The Universal Declaration of Human Rights. Retrieved on February $26^{\text {th }}, 2011$ from http://www.un.org/en/documents/udhr/index.shtml

United Nations (1963) Vienna Convention on Consular Relations. Retrieved on February $26^{\text {th }}, 2011$ from: http://untreaty.un.org/ilc/texts/instruments/english/conventions/9_2_1963.pdf

United Nations (1975). Convention concerning Migrations in Abusive Conditions and the Promotion of Equality of Opportunity and Treatment of Migrant Workers. Retrieved 
on February $26^{\text {th }}, 2011$ from http:/www.ilo.org/ilolex/cgi-lex/convde.pl?C143

Uribe, V.M. (1997). Consuls at work: universal instruments of human rights and consular protection in the context of criminal justice. Houston Journal of International Law, 20(1), 375-424

Verduzco-Igartúa, G.(2008). Lessons from the Mexican Seasonal Agricultural Worker Program in Canada. An Opportunity at Risk. In A. Escobar-Latapí \& S.F. Martin (Eds.), Mexico-U.S. Migration Management. United States: Lexington Books.

Warren, M. (2008). Mexican Consular Protection. Retrieved on July 15 $5^{\text {th }}, 2011$ from: http://www.stratongina.net/glp/node/23 


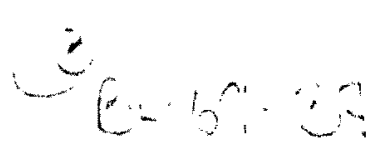

